DEPARTMENT OF THE INTERIOR

U.S. GEOLOGICAL SURVEY

\title{
Cruise Report \\ Hawaiian GLORIA Leg 7, F10-88-HW
}

by

Bonnie A. McGregor1, Ellen S. Kappel2, John B. Wilson33, Fabio Trincardi4 Robert $\mathrm{J}$. Whittington 5 , and Wolf Mayer6, Jon Campbe $11^{7}$

Open-File Report 91-333

1U.S. Geological Survey, Reston, Virginia

2Joint Oceanographic Institutions Incorporated, Washington, D.C.

3 Inst itute of Oceanographic Sciences, Deacon Laboratory, Wormley, United Kingdom

4Istituto Per La Geologia Marina, Bologna, Italy

Institute of Earth Studies, University College of Wales, Aberystwyth, United Kingdom

6 Geology Department, Canberra C.A.E., Belconnen, Australia

7 Institute of Oceanographic Sciences, Deacon Laboratory, Wormley, United Kingdom

This report is preliminary and has not been reviewed for conformity with U.S. Geological Survey (USGS) editorial standards. Any use of trade names is for descriptive purposes only and does not imply endorsement by the USGS. 


\section{INTRODUCTION}

F10-88-HW was the seventh leg of a multiyear program to survey the Hawaiian Ridge Exclusive Economic Zone (EEZ) using the long-range sidescan sonar system, GLORIA (Geologic Long-Range Inclined Asdic). The objective of the systematic surveying of the Hawaiian EEZ is to produce a series of three at lases of images (processed, enhanced, and digitally mosaicked), which display the geologic and morphologic character of the seafloor. These images are the first step toward the evaluation of the resources and potential uses of the U.S EEZ.

With completion of F-12-89-HW in November 1989, the EEZ around the major islands of the State of Hawaii have been imaged, and data collection for the first atlas of the Hawaiian EEZ completed. To date, the EEZ mapping program has published atlases of the EEZ off the conterminous western U.S. (EEZ SCAN 84 Scientific Staff, 1986), in the Gulf of Mexico (EEZ SCAN 85 Scientific Staff, 1987a), around the Commonwealth of Puerto Rico and the U.S. Virgin Islands (EEZ SCAN 85 Scientific Staff, 1987b), and the Bering Sea (Bering Sea EEZ Scan Scientific Staff, 1991). Atlas is in printing for the EEZ off the U.S. East coast. Surveying with GLORIA is complete in the EEZ south of Alaska, adjacent to the Aleutian Islands and in the Gulf of Alaska. The sonar mapping will continue west along the Hawaiian Ridge through 1991.

This 7 th leg (F10-88-HW) surveyed on the leeward side of the Hawaiian Ridge south of the island of Kauai, from the Molokai Fracture Zone on the east to Necker Ridge on the west, and abutted the images collected during 
cruise F5-88-HW to the east (Fig. 1; Torresan et al., 1989). The survey began at the seaward edge of the EEZ and progressed northward to the Hawaiian Ridge to join the images collected on Leg 6 (F6-88-HW) north of Kauai on the windward side of the islands. A suite of geophysical instruments collected data in addition to the GLORIA sonographs. These instruments included: a two-channel seismic reflection profiling system using an air gun sound source, a $3.5 \mathrm{kHz}$ high resolution profiling system, a $10 \mathrm{kHz}$ echo sounder, a towed magnetometer, and a shipboard gravimeter. Expendable bathythermograph (XBT) measurements of the upper 450 meters of the water column were also collected daily.

\section{OPERATIONS}

The GLORIA surveys are conducted from the M/V FARNELLA, a converted freezer trawler under lease to the U.S. Geological Survey through the Institute of Oceanographic Sciences (IOS) in Wormley, U.K. The M/V FARNELLA departed from Honolulu, Hawaii, on schedule at 0900 local time September 28, 1988. Subsequent annotations of day and time in this report will be in Julian Day (day of the year) and in Greenwich Mean Time (GMT). Local Hawaiian time is 10 hours behind GMT, therefore departure from Honolulu was on day 272 at 1900 GMT.

The GLORIA surveying responsibilities are split between IOS and USGS personnel. The IOS participants are responsible for all operations involving GLORIA, as well as for all deck operations and maintenance of the air-gun seismic-reflection system and the $3.5-$ and $10-\mathrm{kHz}$ profiling systems. The USGS personnel are responsible for all aspects of the gravimeter and 
gradiometer operations and for watch-standing duties for everything except GLORIA and the ABC navigation system. The co-chief scientists from the USGS and IOS are jointly responsible for general survey planning and construction of two sets of field mosaics of the GLORIA data.

The tabulations below list the scientific personnel and the schedule of field operations, and review the status of equipment throughout the Leg 7 (F10-88-HW).

\section{SHIPBOARD SCIENTIFIC STAFF FOR F10-88-HW}

\begin{tabular}{|c|c|c|}
\hline Name & Iitle & Affiliation \\
\hline $\begin{array}{l}\text { Bonnie McGregor } \\
\text { Ellen Kappel } \\
\text { Kaye Kinoshita } \\
\text { Lawrence Kooker } \\
\text { Carol Madison } \\
\text { John Fife } \\
\text { Patty Lynch }\end{array}$ & $\begin{array}{l}\text { Co-Chief Scientist } \\
\text { Co-Chief Scientist } \\
\text { Navigator } \\
\text { Electronics Tech } \\
\text { Watch-stander } \\
\text { Watch-stander } \\
\text { Watch-stander }\end{array}$ & $\begin{array}{l}\text { U.S. Geological Survey } \\
\text { Joint Oceanographic Institutions, Inc. } \\
\text { U.S. Geological Survey } \\
\text { U.S. Geological Survey } \\
\text { U.S. Geological Survey } \\
\text { U.S. Geological Survey } \\
\text { National Oceanic and Atmospheric } \\
\text { Administration }\end{array}$ \\
\hline Fabio Trincardi & Geologist & Instituto Per La Geologia \\
\hline John Wilson & Co-Chief Scientist & $\begin{array}{l}\text { Institute of Oceanographic } \\
\text { Sciences }\end{array}$ \\
\hline Jon Campbell & GLORIA Engineer & $\begin{array}{l}\text { Institute of Oceanographic } \\
\text { Sciences }\end{array}$ \\
\hline Graham Lake & Air Gun Tech & $\begin{array}{l}\text { Institute of Oceanographic } \\
\text { Sciences }\end{array}$ \\
\hline & Air Gun Tech & $\begin{array}{l}\text { Institute of Oceanographic } \\
\text { Sciences }\end{array}$ \\
\hline $\begin{array}{l}\text { Robert Whittington } \\
\text { Gareth Knight } \\
\text { Robert Kirk }\end{array}$ & $\begin{array}{l}\text { Geologist, Photographer } \\
\text { ABC Navigation } \\
\text { GLORIA Watch-stander }\end{array}$ & $\begin{array}{l}\text { University College of Wales } \\
\text { Research Vessel Services } \\
\text { Institute of Oceanographic } \\
\text { Sciences }\end{array}$ \\
\hline Nolf Mayer & Geologist & Canberra C.A.E., Australia \\
\hline
\end{tabular}




\section{SCHEDULE OF FIELD OPERATIONS}

On departure from Honolulu, we transited west to the outer edge of the EEZ to the northwestern limit of the Leg 5 (F5-88-HW) survey (Torresan et al., 1989). At this point the survey commenced as a series of 200 to $300 \mathrm{~nm}$ long parallel tracklines oriented NW-SE (course $300^{\circ}$ and $120^{\circ}$; Fig. 2). The tracklines extended from the southern limit of the Molokai Fracture Zone northwestward to just south of Necker Ridge.

1. 272/1900 Depart Honolulu, Hawaii

2. 274/0122 Begin underway watchkeeping start line 1: GLORIA, $3.5 \mathrm{kHz}$, and $10 \mathrm{kHz}$ deployed and gravity measurements recorded. Air gun on line 0228/274 and magnetometer on line 0630/274. See Table 1 for start and end times of the trackline segments.

3. $296 / 0034$ Watches secured survey ends.

4. $297 / 1900$ Arrive in Honolulu, Hawai i

\section{EQUIPMENT REVIEW: COMENTS AND OPERATIONAL LOG}

This review is to summarize the problems and subsequent data gaps with the various systems. Appendix 1 taken from Torresan et al. (1989) summarizes the standard operational procedures for each of the systems. Complete reviews of the trouble shooting and repairs for each system are available in the technicians' logbooks.

Ships generators malfunctioned early in the cruise. On JD 274 intermittent power surges were noted in the $110 \mathrm{~V}$ clean power circuit in the 1ab. At $0823 / 274$ all systems in the lab except GLORIA and the ABC computer system, which were on the $220 \mathrm{~V}$ circuit, were shut down and the generator shifted for the $110 \mathrm{~V}$ circuit only. At $0832 / 274$ all systems were back on line. Two generators were supplying clean power to the lab, $110 \mathrm{~V}$ and 220 $V$, respectively. At $1528 / 276$ both generators failed and all power was lost to the lab. Power failure was caused by failure of a fuse carrying both 
generators. The $220 \mathrm{~V}$ circuit was shifted to the generator supplying the $110 \mathrm{~V}$ power and at 1725/276 all power was restored to the lab. The power failure occurred fortuitously on a tie line so that no data gap occurred.

\section{Gravity Meter}

The gravity meter, a LaCoste Romberg S-53, functioned continuously except for the periods of power outages noted above. Land ties were made at the start and end of the cruise at a dock in Honolulu. Recording of the gravity data began at $0122 / 274$ and continued for the cruise. The gravity data for this cruise should be evaluated carefully because of the interruption in the record caused by the power failures.

$\begin{array}{lll}\text { Time Down } & \text { Time on Line } & \text { Reason } \\ 0819 / 274 & 0900 / 274 & \text { shift generator } \\ 1530 / 276 & 1900 / 276 & \text { Generator problem }\end{array}$

\section{Magnet ometer}

The magnetometer was deployed with the other systems at $0122 / 274$ but the data appeared noisey. The fish was recovered and the hexane in the canister was replaced. Logging of the magnetic field data began at 0900/274 and continued throughout the cruise.

\section{Expendable Bathythermographs (XBT)}

Twelve XВT's were deployed during the cruise. Table 2 lists the locations of the profiles. The probes available were T-4 and T-6, capable of profiling to $460 \mathrm{~m}$ depth. Those deployments that did not show a consistent profile to $460 \mathrm{~m}$ depth were assumed to have fouled in the gear towed astern, and are designated by an asterick in Table 2. 
TABLE 2: XBT Deployment Information

JDay/Time(Z)

of Profile (m)

$275 / 0142$

$276 / 2256$

$278 / 0147$

$281 / 2330$

$282 / 2345$

$283 / 2338$

$284 / 2350$

$286 / 2353$

$287 / 2349$

$289 / 0247$

$289 / 2349$

$293 / 0304$

\begin{tabular}{|c|c|c|}
\hline XBT Type & Latitude $\left({ }^{\circ} \mathrm{N}\right)$ & Longitude $\left({ }^{\circ} \mathrm{W}\right)$ \\
\hline $\begin{array}{l}T-6 \\
T-6 \\
T-6 \\
T-4 \\
T-4 \\
T-4 \\
T-4 \\
T-4 \\
T-4 \\
T-4 \\
T-4 \\
T-4 \\
T-4\end{array}$ & $\begin{array}{l}21^{\circ} 02.2 \\
21^{\circ} 37.6 \\
19^{\circ} 48.1 \\
20^{\circ} 12.7 \\
21^{\circ} 51.2 \\
21^{\circ} 37.1 \\
19^{\circ} 52.3 \\
22^{\circ} 23.5 \\
20^{\circ} 45.7 \\
22^{\circ} 34.3 \\
23^{\circ} 07.6\end{array}$ & $\begin{array}{l}166^{\circ} 09.7 \\
166^{\circ} 38.7 \\
163^{\circ} 15.6 \\
162^{\circ} 18.4 \\
165^{\circ} 21.1 \\
164^{\circ} 22.2 \\
161^{\circ} 07.7 \\
164^{\circ} 41.4 \\
161^{\circ} 37.9 \\
166^{\circ} 07.3 \\
164^{\circ} 54.6\end{array}$ \\
\hline
\end{tabular}

* Profile incomplete XBT fouled

\section{5 kHz High-Resolution Profiling System}

The $3.5 \mathrm{kHz}$ tow fish deployed at $0000 / 273$ did not function. It was recovered and a second fish deployed, which functioned properly. Logging of the data began at $0122 / 274$. The problem with the fish was in the cable connection at the fish, which had not been properly wired. The fish was rewired, although time did not permit testing of the fish. The system functioned well with only minor maintenance.

$\begin{array}{lll}\text { Time Down } & \text { Time on Line } & \text { Reason } \\ 2024 / 283 & 2100 / 283 & \\ 0413 / 284 & 0417 / 284 & \text { paper jam } \\ 0437 / 284 & 0459 / 284 & \text { paper jam } \\ 2032 / 288 & 2034 / 288 & \text { recorder repair } \\ 0024 / 289 & 0136 / 289 & \text { pen change recorder } \\ & & \text { paper jam/recorder repair }\end{array}$

\section{$10 \mathrm{kHz}$ Echo-Sounding System}

The $10 \mathrm{kHz}$ tow fish was deployed at 0000/273 and worked well. Logging of the data began at $0118 / 274$. The system worked well with down time restricted to minor routine maintenance, and blade and paper changes. 


\section{Two-Channel Seismic-Reflection Profiling System}

The seismic reflection profiling system employs a $2600 \mathrm{~cm}^{3}\left(160 \mathrm{cu}^{3}\right)$ air gun sound source and a two channel streamer whose total length, including a stabilizing drag line, is $750 \mathrm{~m}$. Two $50 \mathrm{~m}$ long active sections are towed about 500 to $600 \mathrm{~m}$ behind the sound source.

Parameters for the seismic system included: a 10 second firing rate, a 6 second record length and using the memory capability of the LSR the trace was printed five times for each firing to reduce the vertical exaggeration.

In addition to the times where the lab experienced power outages other causes for the data gaps are listed below. Logging of the data began at $0028 / 274$.

\begin{tabular}{|c|c|c|}
\hline Iime Down & Time on Line & Reason \\
\hline $\begin{array}{l}0816 / 274 \\
0634 / 275 \\
1454 / 275 \\
1530 / 276\end{array}$ & $\begin{array}{l}0830 / 274 \\
0648 / 275 \\
1505 / 275 \\
1753 / 276\end{array}$ & $\begin{array}{l}\text { generator shift } \\
\text { compressor repair } \\
\text { Masscomp crash } \\
\text { gun change and generator } \\
\text { failure }\end{array}$ \\
\hline $\begin{array}{l}0017 / 280 \\
0045 / 285 \\
0411 / 285 \\
1048 / 286 \\
0632 / 290 \\
1130 / 292 \\
1845 / 294 \\
0258 / 295\end{array}$ & $\begin{array}{l}0114 / 280 \\
0136 / 285 \\
0413 / 285 \\
1146 / 286 \\
0725 / 290 \\
1218 / 292 \\
1900 / 294 \\
0305 / 295\end{array}$ & $\begin{array}{l}\text { gun change } \\
\text { gun change } \\
\text { recorder malfunction } \\
\text { Masscomp crash } \\
\text { gun change } \\
\text { recorder malfunction } \\
\text { gun change } \\
\text { gun repair, air pressure }\end{array}$ \\
\hline $0320 / 295$ & $0329 / 295$ & $\begin{array}{l}\text { gun repair, air pressure } \\
\text { loss }\end{array}$ \\
\hline
\end{tabular}

\section{GLORIA Sidescan Sonar System}

The operation of the GLORIA system is covered in extensive logs by the IOS personnel and will not be elaborated upon here. A copy of the pass (one pass equals 6 hours of GLORIA data) record and number of files of GLORIA data is attached as Appendix 2. 
The GLORIA system was launched and began operation at 0122/274. GLORIA operated well for the duration of the survey with the exception of the power failure on day 276 between 1528 and 1725 GMT.

\section{Shipboard Positioning System}

The ABC system (a non-commercial oceanographic computer system provided by IOS) is used for shipboard positioning. It logs data from the various sensors and provides post-processed trackline plots. Both position data and geophysical information (gravity, water depth, and magnetometer/gradiometer) are handled by the $A B C$ system, and can be merged to produce map and section displays. The position data for the system come from the following devices: Global Positioning System (GPS, available for approximately 12 hours/day), transit satellite, and rho-rho Loran C. A USGS system (Normark et al., 1989) provides a real-time trackline display on the ship's bridge as well as in the lab, which shows the ship position relative to the desired survey line. The navigation systems in general functioned well during the cruise.

Time Down

$1955 / 285$
Time on Line

$0100 / 286$

\author{
Reason \\ rho-rho Loran down, \\ computer controller \\ board failure
}

\section{PRELIMIMARY SUMARY OF SCIENTIFIC RESULTS}

The portion of the EEZ south of the Hawaiian Ridge surveyed during F10-88-HW has a mix of tectonic, volcanic, and sedimentologic features. At the outset of the cruise it was thought by the scientific party that a thick blanket of hemipelagic sediment (because of the leeward island setting of the survey) would obscure the diverse tectonic and volcanic features mapped on previous legs. Although the sediments were up to $1 \mathrm{sec}$ thick (2-way travel time), tectonic and volcanic features previously unknown were still mapped. 
The sedimentary sequence itself was far from a uniform drape. Mass wasting processes and ocean-bottom current activity control the distribution of sediments.

The discussion of the preliminary observations and the preliminary scientific results are presented in a sequence of oldest-to-youngest and also basement rocks to recent sediments. Observations and preliminary interpretations are based on daily shipboard discussions. Consensus was not always achieved so alternate hypotheses are also presented.

\section{Molokai Fracture Zone}

The eastern 1 imit of the F10-88-HW survey area includes partial coverage of the Molokai Fracture Zone (MFZ) south of the Hawaiian Islands, and overlaps the western edge of the GLORIA coverage of cruise F5-88-HW (Torresan et al., 1989). Where imaged, the MFZ south of the Hawaiian Islands is recognized as a zone of lineaments (trending about 0750) of high backscatter, which are interpreted to be a series of faulted volcanic ridges. In cross section the lineaments are asymmetric with the steeper slope facing east. Toward the northeastern limit of our survey area the MFZ is covered by a progressively thicker drape of sediment so that by $20^{\circ} 10^{\prime} \mathrm{N}, 158^{\circ} 30^{\prime} \mathrm{W}$, the MFZ can no longer be seen on the sonar images (Torresan et al., 1989). We did not image the southern termination of the MFZ that extends beyond the $200 \mathrm{~nm}$ limit of the EEZ.

The MFZ is approximately $40 \mathrm{~km}$ wide where it can be measured at $19^{\circ} 30^{\prime} \mathrm{N}$, $161^{\circ} 30^{\prime} \mathrm{W}$, but clearly narrows to the north toward the island chain. It widens again north of the islands from where it emerges from the sediment 
cover, and has been measured to be as wide as $130-150 \mathrm{~km}$ (Normark et al., 1989). The westernmost fracture of the MFZ south of the Hawaiian Islands that was imaged during the F10-88-HW cruise appears to line up with the westernmost strand of band "D" of the MFZ as described by Normark et al. (1989). Similarly, the easternmost band of fractures that define the MFZ south of the Hawaiian Islands appears to line up with the easternmost limit of band "A" of the MFZ north of the Hawaiian Islands described by Normark et al. (1989). The continuation of strands across the Hawaiian Ridge suggests that " $A$ " and "D" are of the same age and that bands " $B$ " and "C" of Normark et al. (1989) are younger. The westernmost strand south of the chain is a continuous feature that trends $075^{\circ}$, whereas the remainder of the fracture zone is a series of en echelon slivers that trend between $074^{\circ}$ and $080^{\circ}$. It is difficult to measure the length of the strands because of incomplete sonar coverage of the MFZ.

Offset of the igneous basement across the MFZ, measured on the air gun records, is as great as $900 \mathrm{msec}$ (two-way travel time), but displacement of 600-700 msec is also seen on records of our three other crossings of this feature. The $3.5 \mathrm{kHz}$ echosounding records show that the ridges are draped with some sediment.

There is no free air gravity anomaly over the MFZ and the magnetometer data (low amplitude anomalies) are consistent with the interpretation that the MFZ and adjacent seafloor formed in the Cretaceous.

\section{Kauai Fracture Zone}

Approximately $110 \mathrm{~km}$ north and west of the MFZ is a continuous northeast-trending $\left(075^{\circ}\right)$ band of lineaments similar in sonar character to 
that of the MFZ (Fig. 3). We interpret this feature to be another fracture zone distinct from the Molokai. We have informally named this fracture zone the Kauai Fracture Zone (KFZ) because of its projected intersection with the eastern margin of the island of Kauai. There is no free-air gravity anomaly present on the records of any of the nine crossings made of the KFZ (therefore it is isostatically compensated), and the Cretaceous seafloor grain is orthogonal to and bends in toward the fracture zone. Thus, we interpret this newly recognized fracture zone also to be of Cretaceous age.

The trend of the $\mathrm{KFZ}\left(075^{\circ}-078^{\circ}\right)$ is similar to that of the MFZ in this region south of the Hawaiian Islands and does not intersect the MFZ in our survey area. If we project the KFZ north of the Hawaiian Islands, it may align with a single volcanotectonic lineament imaged during the F4-88-HW cruise of Normark et a1. (1989). This is consistent with the observation that the KFZ is wider in the southern part of our survey area $(65 \mathrm{~km}$ at $\left.20^{\circ} 00^{\prime} \mathrm{N}\right)$ than farther north $\left(40 \mathrm{~km}\right.$ at $\left.20^{\circ} 40^{\prime} \mathrm{N}\right)$, implying that this fracture zone fans out to the south. However, we did not image the $\mathrm{KFZ}$ from $150 \mathrm{~km}$ south of the island chain and the volcanotectonic lineament is first recognized about $200 \mathrm{~km}$ north of the islands, so that the apparent tectonic connection between these two features may not be real. Also, the northern lineament is a much more prominent seafloor feature and may be younger than the Cretaceous KFZ. Although these two features may not be linked, there is a small offset in the magnetic anomalies between the MFZ and the Murray Fracture Zone north of the Hawaiian chain (see Plate Tectonic Map of the Circum-Pacific Region). We suggest that the KFZ may be where that offset occurs. 
Relief of the KFZ ridges does not exceed $650 \mathrm{~m}$ where measured on the echosounding records, and overall relief diminishes toward the north. The ridges are asymmetric with the steeper slopes facing east and are covered by thin sediment drape.

Sediment-filled grabens occurred within the KFZ, especially along the southern $2 / 3$ of our survey area (south of Line 17). In some places the sediment is as thick as $400 \mathrm{msec}$ (two-way travel time). Basement displacement across the KFZ, measured on the air gun records, is as great as $1000 \mathrm{msec}$, but is variable along its length. The basement is offset down toward the east.

\section{Major Seafloor Ridges}

Two prominent subparallel ridges, which are suggestive of "leaky" fractures, slice the seafloor, vertically displacing the crust west of the Kauai Fracture Zone. We have informally named these "leaky" fractures East Nihoa Ridge and West Nihoa Ridge because they are projected to intersect the Hawaiian Ridge east and west of Nihoa Island (Fig. 1). On the GLORIA images they are recognized as continuous linear ridges of extremely high backscatter, and are in excess of $340 \mathrm{~km}$ (East Nihoa Ridge) and $270 \mathrm{~km}$ (West Nihoa Ridge) in length (Fig. 4). The ridges trend $071^{\circ}$ and $062^{\circ}$, respectively. Also, the ridges have large negative magnetic anomalies where crossed, and we recorded free air gravity highs at those points suggesting that East Nihoa and West Nihoa Ridges are Tertiary in age and formed during a period when the earth's magnetic field was reversed.

Both ridges appear to consist of volcanic material along their length, and they are up to $1000 \mathrm{~m}$ high at their crests. The volcanic ridges are 
asymmetric, with their steep slopes facing east, and they have little to no measurable sediment cover. The sonar images show that beyond the limit of the continuous volcanotectonic features, a string of discrete volcanoes can be traced as an extension of the tectonic trend (Fig. 4). The volcanoes have rounded tops and steep sides that are acoustically bright. The average diameter of the volcanoes as measured across the bright rims is between 5-10 $\mathrm{km}$, but some are smaller. East and West Nihoa Ridges end in a line of discrete volcanoes, which may form because of the loss of hydraulic head of the magma at the fracture tips during volcanic extrusion episodes.

Vertical displacement of the igneous basement is greatest along the West Nihoa fracture, and is measured on five crossings to be from $60-380 \mathrm{msec}$ (two-way travel time). The variation in offset of the basement appears to be random. Vertical displacement across East Nihoa Ridge is much less than that of West Nihoa, and where measured does not exceed $160 \mathrm{msec}$; no vertical displacement of the basement was seen on most of the eight crossings of this feature. However, where observed, the present seafloor steps down to the southeast across both of these fractures.

The main segments of East and West Nihoa Ridges overlap for $130 \mathrm{~km}$ between $22^{\circ} \mathrm{N}, 165^{\circ} \mathrm{W}$ and $21^{\circ} \mathrm{N}, 163^{\circ} 50^{\prime} \mathrm{W}$ where they intersect the projection of the Hawaiian arch in this region. The Hawaiian arch is a subtle upward bending of the oceanic lithosphere resultng from the load imposed upon it from the younger Hawaiian volcanoes (Watts et al., 1985). The overlapping segments to curve toward each other similar to the geometry recognized along overlapping spreading centers of the East Pacific Rise (e.g., Macdonald and Fox, 1983; Macdonald et al., 1984). It is more apparent that West Nihoa Ridge curves toward East Nihoa Ridge, though it is a bit more ambiguous 
whether East Nihoa bends west (Fig. 4). The termination of East Nihoa Ridge may be traced in one of two sets of small volcanoes; one set clearly curves toward West Nihoa, but the other is straighter and continues along a slightly more easterly trend away from East Nihoa Ridge. This evidence, along with aninferred post-Cretaceous age of the features, suggests that the fractures formed in response to lithospheric loading of the seafloor as a result of volcanism along the Hawaiian chain. The fractures affect the lithosphere and leaked magma.

\section{Necker Ridge}

Necker Ridge is a major elongate volcanic feature that defines the western limit of our survey area. The ridge is nearly $3000 \mathrm{~m}$ high, is symmetric in cross-section, and is $25 \mathrm{~km}$ wide at $22^{\circ} 30^{\prime} \mathrm{N}$, narrowing to $19 \mathrm{~km}$ at $23^{\circ} \mathrm{N}$. Necker Ridge terminates at about $23^{\circ} 15^{\prime} \mathrm{N}$ against the Hawaiian Ridge. Both sediment cover and igneous basement are vertically displaced by about $150 \mathrm{~m}$ on either side of the ridge (they are lower to the east). Out ship tracks run parallel to ridge $\left(058^{\circ}\right)$ and are just off the ridge, and thus GLORIA provides us with excellent images of ridge-parallel structure.

Necker Ridge is recognized on GLORIA images by its high acoustic backscatter from slopes measured to have a gradient of $1: 3$ (about $20^{\circ}$; Fig. 5). The slopes, or shoulders, of the ridge are virtually unbroken, displaying only a few mappable fissures. The shoulders have a shingled appearance that we interpret to be overlapping bulbous lava mounds similar to those described from SeaMARC I images of the Juan de Fuca Ridge (Kappel and Ryan, 1986). The mounds have outward-facing steep edges, are generally aligned parallel to contour, and have a fairly uniform width of about $5 \mathrm{~km}$. At two crossings of these features 
along the base of Necker Ridge, the echosounding records show them to have flat tops. Where the summit of Necker Ridge was imaged, we are able to identify irregular topography and a long, narrow perched basin.

Several semi-circular areas of higher backscatter (relative to the surrounding sedimented seafloor) are recognized at the base of Necker Ridge. We interpret these areas to be small (about 2-3 $\mathrm{km}$ wide) debris piles. One large slide is observed at $22^{\circ} 55^{\prime} \mathrm{N}$ latitude on the eastern side of the ridge that has a width near the base of Necker Ridge of $24 \mathrm{~km}$ and has traveled as far as $18 \mathrm{~km}$ from the base of the ridge.

Necker Ridge has a negative magnetic anomaly, but does not have a significant free-air gravity anomaly.

\section{Seafloor Volcanoes}

Two types of volcanoes dot the seafloor in our survey area south of the Hawaian Island chain. One type is a nearly perfect circle with a narrow but distinct acoustically bright rim, suggesting that they have very steep sides (Figs. 4 and 5). This type of volcano is typically 400-500 $\mathrm{m}$ in height, with rounded summits that sometimes have craters. The geophysical profiles that cross these volcanoes show measurable sediment cover on them. There is no evidence on the sonar images or subbottom profiles of a more gently sloping base as might be expected of a volcano. This type of volcano is generally found to the west of the Kauai Fracture Zone and appears to occur in chains rather than randomly on the seafloor, suggesting that the volcanoes form along seafloor fractures that are not imaged by GLORIA. Similar volcanoes were mapped on the East Pacific Rise and related to fracture zones (Batiza and Vanko, 1984). Where we have data, volcanos of this type have negative magnetic anomalies and thus we infer a Tertiary age for these features. 
The second type of volcano has a more typical seamount cross-section, and has a gently sloping base of high backscatter and a conical sumit (Fig. 6). These volcanoes are less abundant than those described above; we imaged only 7 of them as compared with over 50 of the type 1. These conical seamounts are similar in size, and have a base that is about $20-25 \mathrm{~km}$ in diameter as measured on the GLORIA images. The ship's track only crossed one of these volcanoes at its summit, which measured $2500 \mathrm{~m}$ in height from the seafloor. In plan view, a radial pattern, similar to spokes on a bicycle wheel, is seen on the flanks of the seamounts. The pattern results from imaging downslope-trending ridges and valleys. The flanks of all of the seamounts with these pronounced ridges and valleys also appear to be eroded, though we see no evidence of debris aprons at their base. This type of volcano occurs only north of the KFZ, north of about $21^{\circ} \mathrm{N}$ and in a cluster. They do not appear to be associated with any obvious basement fractures as are most of the smaller volcanoes. Also, these seamounts all have relatively large free-air gravity highs over them, but not all of them are negatively magnetized. We interpret the seamounts to be variable in age, possibly post-Cretaceous, despite the ambiguity in the magnetic data. These seamounts look very similar to the Cross Seamounts south of the island of Hawai (Torresan et al., 1989).

\section{Cretaceous Seafloor}

Igneous basement formed at the Cretaceous ridge crest is exposed only at the fractures zones in our survey area. Elsewhere, the north-south trending Cretaceous seafloor grain is only observed on the GLORIA images between the MFZ and $\mathrm{KFZ}$, between $163^{\circ} \mathrm{W}$ and $163^{\circ} 30^{\prime} \mathrm{W}$ and $19^{\circ} 30^{\prime} \mathrm{N}$ and $20^{\circ} \mathrm{N}$ where it is covered by at least $200 \mathrm{msec}$ (two-way travel time) of sediment. The 10 
$\mathrm{kHz}$ records show broad morphologic highs where the seafloor grain is recognized on the sidescan images, and there is an indication of rotated igneous blocks on the air gun profiles.

Across all of the linear tectonic features in this area, the seafloor and basement are displaced down to the east. For the MFZ and KFZ, this offset would be consistent with older seafloor on the east side of each fracture zone. The bending of the Cretaceous seafloor grain which intersects the KFZ shows the offset is sinistral, which is consistent with older seafloor on the east side. The off set across Necker and East and West Nihoa Ridges is curious because the ridges apparently post-date Cretaceous seafloor formation and are more recent features. Possibly the offset is related to loading of the lithosphere by the Hawaiian Ridge. The detailed mapping of seafloor spreading magnetic anomalies in this region would help to confirm and better determine the Cretaceous seafloor spreading geometry.

\section{Young Volcanic Flows}

The GLORIA sonar system imaged several patches of extremely high acoustic backscatter surrounding the small island of Kaula (Fig. 7). Across these acoustically bright patches, the $3.5 \mathrm{kHz}$ profiles show a mushy subbottom that we interpret to be lava flows. Lava flows have been imaged on several cruises in the Hawaiian Islands area (Holcomb et a1., 1988; Lipman et al., 1989; and Clague et al., 1990).

Within the bright patches are several areas, a few kilometers across that have lower backscatter and are likely kipukas. The source of the flows cannot be identified from our data but they do not appear to originate from either Kaula or Niihau Islands, the largest volcanic centers in the area. 
One lava flow, located at about $22^{\circ} \mathrm{N}, 161^{\circ} 10^{\prime} \mathrm{W}$, covers an area at least $35 \mathrm{~km}$ in length and $25 \mathrm{~km}$ in width. The surface appears smooth and unbroken on the sonar images, and the generally radial shape of the flow implies that the lava flowed unimpeded by any topographic highs from its source. This flow covers an older flow, part of which can be traced adjacent to the younger one. The older flow is recognized by its lower acoustic backscatter.

Another lava flow, at least $14 \mathrm{~km}$ wide and $11 \mathrm{~km}$ long, was mapped at $22^{\circ} 10^{\prime} \mathrm{N}, 161^{\circ} 20^{\prime} \mathrm{W}$. This lava flow abuts a debris slide and appears to have covered part of it. In contrast to the flow described above, the surface of this flow appears to be more like a large blister, i.e., has a very gently sloping surface, rather than a flat one, suggesting perhaps a slower rate of volcanic effusion, a lower seafloor slope than the flow described above, or a rougher seafloor surface that would inhibit spreading.

A cluster of small volcanic cones, 2-5 $\mathrm{km}$ in diameter are recognized in this same area of the lava flows. The cluster consists of three cones and is located at about $21^{\circ} 50^{\prime} \mathrm{N}, 160^{\circ} 40^{\prime} \mathrm{W}$, north of Kaula Island. All the cones have craters at their summit. The cones do not appear to be the source of the flows because they are not within areas of high acoustic backscatter. Instead, the cones are within a patch of relatively low backscatter.

\section{Sediment Distribution and Transport Pathways}

Sediment thickness varies greatly within the Hawaiian EEZ. In general, the thickness of sediment appears to be greater to the south and west of the islands than to the north and east, which is not surprising given the southwesterly direction of the trade winds. North and east of the islands, the north-south trending Cretaceous seafloor grain can clearly be seen on the 
GLORIA imagery as lineations of high backscatter (Normark et al., 1989). On the images from the lee side of the islands, the Cretaceous seafloor grain appears as bands of very subtle backscatter changes with sediments blanketing and masking the basement relief (Fig. 3; Torresan et al., 1989 and this study).

Sediment distribution within our survey area south and west of the Hawaiian Ridge also varies greatly. The sediment blanket is greatest on the east side of Necker Ridge where it approaches $1 \mathrm{sec}$ (two-way travel time), or $750 \mathrm{~m}$ (assuming $1500 \mathrm{~m} / \mathrm{sec}$ velocity), in thickness. A well-stratified turbidite sequence thickens as a wedge from West Nihoa Ridge to Necker Ridge, and ponds against the ridge. Although the sediment thickness varies, it averages from 150 to $250 \mathrm{msec}$, but is generally thickest (350-540 msec) near the Hawaiian Ridge and thinner towards the Hawaiian Arch. Locally the sediments are up to 400 to $500 \mathrm{msec}$ thick in grabens within the fracture zones. Because the fracture zones become progressively buried by sediments as they approach the Hawaiian Ridge, they serve as conduits for sediment transport to the southwest, away from the islands.

An unconformity was identified on the air gun records over much of the area, approximately one-third of the depth into the sediment column. This unconformity more closely follows the basement topography, rather than the seafloor irregularities. Although it needs to be mapped in detail with tie lines of subbottom data and samples where it is interpreted to crop out at or near the seafloor, this unconformity is believed to mark a major change in the depositional pattern in the area. This change is from an older stratified sequence that drapes the basement irregularities to a sequence that is variable in thickness and onlaps basement highs, suggestive of 
sediments being transported by turbidity currents. In places the upper unit terminates in low angle downlap and may reflect local talus deposits along the base of some of the steep sides of basement ridges. Downlap also occurs at the edge of large scale depositional mounds. Without processing of air gun data to remove the bubble pulse, a more detailed mapping and characterization of the unit is not possible. We suggest that this major change may reflect migration of the hotspot and formation of the Hawaiian Ridge in the area.

\section{Recent Sedimentary Processes}

The $3.5 \mathrm{kHz}$ profiles help define the depositional patterns in the surface and near surface sediments. Preliminary mapping of the acoustic facies revealed by the $3.5 \mathrm{kHz}$ data allow us to identify sedimentary units and infer the sedimentary processes influencing major areas. In general, significant differences in surface sediments occur from the southwestern edge of the EEZ toward the Hawaiian Ridge. Other significant differences occur in proximity to the volcanic features which crop out on the seafloor.

The most recent acoustic unit was mapped from the seaward edge of the EEZ to the Hawaiian Arch. It is acoustically transparent to occasionally weakly stratified and has a variable thickness between 0 and $50 \mathrm{~m}$, and a patchy distribution. It is thickest between Necker Ridge and Nihoa East Ridge at the edge of the EEZ. The surface of the transparent unit is marked by a weak reflector whereas the base of the unit, although laterally variable, has a strong prolonged return that inhibits further acoustic penetration. The geometry of the transparent unit has four expressions: 1) sheet drape over the bottom morphology, 2) wedging, which indicates a uniform direction of thinning over long distances, 3) lense or mound shape with a 
maximum thickness at the center and wedging out at its edges, and 4) thickness variations across small topographic highs with increased thickness on the lee side. The first geometric expression is indicative of hemipelagic drape. The systematic occurrance of the maximum thickness of the unit on topographic highs indicates some possible current activity in the low areas where winnowing or local erosion may cause a decrease in the unit thickness relative to the highs. Either distal low density turbidity currents or ocean currents can explain the geometric expressions of 2,3 , and 4 . We believe that this acoustically transparent unit is made up of fine-grained hemipelagic sediments; however, its patchy distribution and variable thickness suggest that it may be composed of distal turbidites that originate from mass wasting processes that occur on the flanks of the Hawaiian Ridge.

Perched basins on the volcanic highs of the KFZ and East and West Nihoa Ridges have sediment fill of 60-90 meters, documenting the existance of hemipelagic deposition in the area.

Although bottom water currents are present, they are probably characterized by low mean flow since they are not very erosive. Minor erosional moats were identifiable on subbottom profile data in only a few places, mainly on crossings of East and West Nihoa Ridge and around some of the seamounts. These moats are a few hundred meters wide and resemble those shown in Fig. 13 by Lonsdale, et al. (1972) at the base of Horizon Guyot and described in the Line Island Archipelago by Normark and Spiess (1976). They used direct current measurements and bottom photographs to document the acceleration of slow oceanic currents around basement obstacles. More common in our study area was a slight depression formed by wedging out of the 
transparent unit caused by nondeposition or winnowing near East and West Nihoa Ridges. A 5-6 km wide zone of strong bottom return with no subbottom was present adjacent to the ridges. Away from the ridges the bottom of the depression is seen to correlate with a subbottom reflector beneath the transparent unit. Within the depression, however, winnowed coarser material may be present although not resolvable on the $3.5 \mathrm{kHz}$ records. On the GLORIA mosaic, halos of high backscatter are found around the base of volcanic highs and correspond generally to the areas where the transparent unit has pinched out according to the $3.5 \mathrm{kHz}$ data. The distribution of this band with no or very little subbottom penetration was not random. It was present on the south side of West Nihoa Ridge. The current direction required to produce this pattern is not obvious. Other areas of high backscatter halos around basement highs are suggestive of debris aprons fed by the local eroding volcanic slopes.

Clear evidence of bottom currents is indicated by bedforms in the floor of the Molokai Fracture Zone. The bedforms are approximately $2 \mathrm{~m}$ in amplitude and $1 \mathrm{~km}$ in wavelength (Fig. 8). The MFZ narrows adjacent to thebedforms, which probably increases the flow velocity. Bedforms bow slightly in the center of the MFZ relative to the walls suggesting that the flow is along the MFZ from southwest to northeast. The crests of the bedforms trend $118^{\circ}$. Down flow the bedforms seem to be more current (fracture zone) parallel than the earlier transverse orientation. This same area was imaged in April 1988 (JD 112 and 113) on Leg 5 (F5-88-HW) and we identify bedforms on the mosaic as well. The orientation of the bedforms in April 1988 was parallel to the MFZ $\left(080^{\circ}\right)$ and no doubt current parallel. This suggests a change in bottom currents between April and October of sufficient strength and duration to reorient the bedforms. 
A variety of mass wasting landforms including rotational slumps, slides, debris flows, sediment waves, or bedforms of fine-grained sediment are prominent in the survey area. The dimensions of the features are highly variable. Necker Ridge has several small debris flows or talus piles approximately $1 \mathrm{~km}$ in diameter, which we described earlier. The largest features are slides that cover areas over $60 \times 120 \mathrm{~km}$ across.

Slumps were characterized on the GLORIA images as linear ridges trending generally parallel to the contours on the flank of the Hawaiian Ridge. The ridges appear to be asymetric features with the steeper flank facing upslope caused by the back rotation at the head of the slump. Relief on the ridges is of the order of 20 meters where the ship crossed them. These slumps occur on the sedimented slopes where the sediment thickness is approximately $250 \mathrm{~m}$.

Slides are characterized by fields of large displaced blocks. The blocks appear as high backscatter targets on the imagery. Relief on the blocks is variable but often is of the order of $100 \mathrm{~m}$ and their length is of the order of kilometers. They have been displaced approximately $60 \mathrm{~km}$. Because of their high backscatter and size, they are interpreted to be blocks of volcanic material that have resulted from the collapse of the Hawaiian Ridge. The Alika slide off the island of Hawaii (Normark et al., 1987; Lipman et a1., 1988) is an example of these features. Numerous other slides around the Hawaian Islands are described by Moore et al. (1989).

Debris flows appear as regions of high backscatter, trending down slope and are chute-like in appearance on the slope of the Hawaiian Ridge. Distally (over $50 \mathrm{~km}$ from the base of the Ridge) they terminate as fingers 
with higher backscatter than the surrounding seafloor. The irregular character of the bottom return on the $3.5 \mathrm{kHz}$ indicate a surface roughness, with relief below the resolution of the system.

Sediment waves or large bedforms cover areas $10^{\prime} \mathrm{s}$ of kilometers across where the seafloor gradient is low. The seafloor is hummocky with tens of meters of relief. The internal stratification shows a climbing bedform-type of geometry. These features are believed to be depositional in origin, resulting from deposition from a sediment flow. They are similar to features observed on GLORIA images of submarine fans (EEZ Scan 84 scientific staff, 1986; and EEZ Scan 85 scientific staff, 1987).

One slide is present at the edge of the EEZ near $20^{\circ} \mathrm{N}, 165^{\circ} 30^{\prime} \mathrm{W}$ on the flank of the Kauai Fracture Zone. It covers an area $50 \times 75 \mathrm{~km}$, but may represent more than one event. The slide is composed of discrete blocks, having up to $70 \mathrm{~m}$ of relief and 1 to $2 \mathrm{~km}$ in width. There is no obvious source for this slide within the EEZ. The largest topographic feature near by is Horizon Guyot, but East Nihoa Ridge may well be a barrier to sediment transport from that area. The other possible source is the KFZ itself. The slide fringes the northern ridge of the fracture zone. Whether the fracture zone outside the survey area has sufficient relief and steepness to spawn a slide is not known. Slides are not seen associated with the volcanoes at $21^{\circ} 30^{\prime} \mathrm{N}, 165^{\circ} \mathrm{W}$, which are interpreted to be extensively eroded, so that a large volcanic pile must be necessary for slope collapse to occur. The origin of this slide remains a mystery.

Most of the slides are located adjacent to the Hawaiian Ridge and have originated from it. One large slide has originated from Necker Island (Fig. 9). Part of the debris slid down the northwest side of Necker Ridge, but most of it went to the southeast. Failure appears to have been in three 
phases. First, rotational slumps occurred producing a series of ridges with approximately a $2 \mathrm{~km}$ wavelength. A second phase of failure resulted in a slide of large blocks covering a $40 \times 60 \mathrm{~km}$ fan-shaped area with the apex of the fan on a basement high on the slope. On either side of the slide, a sheet-like flow of smaller debris has partially buried the slump folds on one side and resulted in a series of sediment waves on the other. Total area covered by displaced sediments of Necker Slide is $14,000 \mathrm{~km}^{2}$. An alternative explanation for the slump folds is that they are sediment waves formed by bottom water currents interacting with the topography at the juncture of Necker Ridge with the Hawaiian Ridge. The interaction of bottom currents and topography have been described by Cacchione et al., (1988) and Schwab et al., (1988) on Horizon Guyot. The corner formed by the topography might help focus and intensify the bottom water flow to produce sediment waves. There also are similar sediment wave-like features on the northwest side of the juncture of Necker and the Hawaiian Ridge. Opposing bottom current flow to the north, south of Necker Ridge and to the south, north of the ridge would be necessary and seems unlikely. Also, the proximity of the sediment waves to the slide seems to be more than just a coincidence.

Debris chutes and blocky slides are present all along the Hawaiian Ridge from Necker Island to Kaula. Large sediment slumps are present on the flank of the Hawaiian Ridge near $23^{\circ} \mathrm{N}$ and $163^{\circ} \mathrm{W}$, and adjacent to Nihoa Island. A slide imaged on Leg 6 (F6-88-HW) is present upslope from the slump adjacent to Nihoa island and may have triggered the slump. Near Kaula Island, the lava flow, which we described earlier, has triggered sediment failure on the adjacent slope. An area 90 by $60 \mathrm{~km}$ has undergone sediment failure. 
Adjacent to the flow, ridges of deformed sediment have relief of 20 to $30 \mathrm{~m}$ and decrease in size downslope until they are no longer resolvable on the 3.5 $\mathrm{kHz}$ records except as an irregular acoustic return caused by micro relief. The seafloor for a distance of $60 \mathrm{~km}$ down the slope has the appearance of a wrinkled carpet cased by the lava flow pushing on the sediment at the top of the slope (Figure 10).

The GLORIA mosaic shows evidence of sediment transport processes far removed from the Hawaiian Ridge. Regions of slightly higher backscatter than the surrounding seafloor are present between the Kauai Fracture Zone and West Nihoa Ridge. These regions have lineations that we believe represent flow events. Verification studies with additional high resolution tools will be necessary to understand what the differences in acoustic backscatter represent.

\section{SUMARY}

This is only a preliminary discussion to highlight the major observations from this cruise and to assist in accessing the data for future studies. More detailed study and seafloor samples will be necessary to understand the implications of all that we have observed. 


\section{References}

Batiza, R., and Vanko, D., 1984, Volcanic development of small oceaniccentral volcanoes on the flanks of the East Pacific Rise inferred from narrow-beam echo-sounder surveys: Marine Geology, v. 54, p. 53-90.

Bering Sea EEZ-Scan Scientific Staff, 1991, Atlas of the U.S. Exclusive Economic Zone Bering Sea, U.S. Geological Survey Miscellaneous Investigation Series I-2053, 145 p.

Cacchione, D.A., Schwab, W.C., Noble, M., and Tate, G., 1988, Internal tides and sediment movement on Horizon Guyot, Mid-Pacific Mountains:

Geo-Marine Letters, v. 8, p. 11-17.

Clague, D.A., Holcomb, R.T., Sinton, J.M., Detrick, R.S., and Torresan, M.E., 1990, Pliocene and Pleistocene alkalic flood basalts on the seafloor north of the Hawaiian Islands: Earth and Planetary Science Letters, v. 98, p. 175-191.

EEZ SCAN 84 Scientific Staff, 1986, At las of the Exclusive Economic Zone western conterminous United States: U.S. Geological Survey Miscellaneous Investigation Series, I-1792, $152 \mathrm{p}$.

EEZ SCAN 85 Scientific Staff, 1987a, Atlas of the Exclusive Economic Zone Gulf of Mexico: U.S. Geological Survey Miscellaneous Investigation Series I-1864A, 104p.

EEZ SCAN 85 Scientific Staff, 1987b, Atlas of the Exclusive Economic Zone Eastern Caribbean Area: U.S. Geological Survey Miscellaneous Investigation Series I-1864B, 58p.

Holcomb, R.T., Moore, J.T., Lipman, P.W., Belderson, R.H., 1988, Voluminous submarine lava flows from Hawaiian volcanoes: Geology, v. 16, p. 400-404.

Kappel, E.S., and Ryan, B.F., 1986, Volcanic episodicity and a non-steady state rift valley along northeast Pacific spreading centers: Evidence from Sea MARC I: J. Geophys. Res., v. 91, p. 13,925-13,940.

Lipman, P.W., Normark, W.R., Moore, J.G., Wilson, J.B., and Gutmacher, C.E., 1988, The giant submarine Alika debris slide Mauna Loa, Hawaii: Journal of Geophysical Research, v. 93, p. 4279-4299.

Lipman, P.W., Clague, D.A., Moore, J.G., and Holcomb, R.T., 1989, South Arch volcanic field-newly identified young lava flows on the seafloor south of the Hawaiian Ridge: Geology, v. 17, p. 611-614.

Lonsdale, P., Normark, W.R., and Newman, W.A., 1972, Sedimentation and erosion on Horizon Guyot: Geological Society of America Bulletin, v. 83, p. 289-316.

Macdonald, K.C., and Fox, P.J., 1983, Overlapping spreading centers: new accretion geometry on the East Pacific Rise: Nature, v. 302, p. 55-58. 
Macdonald, K.C., Sempere, J.-C., and Fox, P.J., 1984, East Pacific Rise from Siqueiros to Orozco Fracture Zones: along-strike continuity of axial neovolcanic zone and structure and evolution of overlapping spreading centers: J. Geophys. Res., v. 89, p. 6,049-6,069.

Moore, J.G., Clague, D.A., Holcomb, R.T., Lipman, P.W., Normark, W.R., and Torresan, M.E., 1989, Prodigious submarine landslides on the Hawaiian Ridge: Journal of Geophysical Research, v. 94, p. 17,465-17,484.

Normark, W.R., and Spiess, F.N., 1976, Erosion on the Line Islands archipelagic apron: effect of small-scale topographic relief: Geological Society of America Bulletin v. 87, p. 286-296.

Normark, W.R., Holcomb, R.T., Searle, R.C., and Somers, M.L., 1989, Cruise report, Hawaiian GLORIA legs 3 and 4, F3-88-HW and F4-88-HW: U.S. Geological Survey Open-File Report 89-213, 57p.

Schwab, W.C., Lee, H.J., Kayen, R.E., Quinterno, P.J., and Tate, G.B., 1988, Erosion and slope instability on Horizon Guyot, Mid-Pacific Mountains: Geo-Marine Letters, v. 8, p. 1-10.

Torresan, M.E., Shor, A.N., Wilson, J.B., and Campbell, J., 1989, Cruise Report, Hawaiian GLORIA Leg 5, F5-88-HW: U.S. Geological Survey Open-File Report 89-198, 56p.

Watts, A.B., U.S. ten Brink, Buhl, P., and Brocher, T.M., 1985, A multichannel seismic study of lithospheric flexure across the Hawaiian-Emporer seamount chain: Nature, v. 315, p. 105-111. 
APPENDIX 1 


\section{EQUIPMENT SETTINGS AND COMENTS}

F10-88-HW

1. $3.5 \mathrm{kHz}$ System

$\begin{array}{lll}\text { LSR (Recorder) } & \text { MODE } & \text { Continuous } \\ & \text { PAPER } & 100 \text { lines/inch } \\ & \text { SWEEP } & 1 \text { second } \\ & \text { PROGRAM } & \text { As required } \\ \text { GaIN } & \text { Mariable } \\ & \text { CONTRAST } & \text { Mid-range } \\ & \text { THRESHOLD } & \text { Low to mid-range } \\ \text { PTR Transceiver } & \text { GAIN } & \begin{array}{l}-7.5 \text { low (fixed: ramp } \\ \text { control not active) }\end{array} \\ & \text { POWER } & \begin{array}{l}0 \text { db } \\ \text { PULSE WIDTH }\end{array} \text { Controls not active } \\ \text { IOS Correlator } & \text { OUTPUT LEVEL } & 4 \\ & \text { ATTENUATOR } & 11.5\end{array}$

Fish depth compensation is set at $15 \mathrm{~m}$. Instructions for time and cruise ID are in the manual provided.

2. $10 \mathrm{kHz}$ System

$\begin{array}{lll}\text { MUFAX RECORDER } & \text { ATTENUATOR } & -12 \\ & \text { PULSE LENGTH } & 2.8 \mathrm{msec} \\ \text { TIME MARKS } & 6 \mathrm{~min} \text { intervals } \\ \text { FISH DEPTH } & 6 \mathrm{~m} \\ \text { GATING INT } & 6 \mathrm{sweeps} \\ \text { SCALE } & 2 \mathrm{sec} \\ \text { SCALE } & \begin{array}{l}1500 \mathrm{~m} / \\ \text { PROGRAM }\end{array} & \begin{array}{c}\text { Edge or center key; allows } \\ \text { scale changes of } 1 \mathrm{sec} \text { intervals }\end{array} \\ & \text { TVG } & \begin{array}{c}\text { Can be used to suppress the } \\ \text { outgoing pulse }\end{array} \\ & \end{array}$

Note: The TVG is normally on when GATING is on, and vice versa.

3. Seismic reflection system (two channel)

$\begin{array}{lll}\text { Sound Source } & \text { AIR GUN } & 160 \mathrm{in}^{3} \\ & \text { FIRING RATE } & 10 \mathrm{sec} \\ \text { Receiver } & 2 \text { CHANNEL } & 50 \mathrm{~m} \text { act ive sections }\end{array}$




$\begin{array}{lll}\text { LSR (Receiver) } & \text { DISPLAY } & \text { Normal } \\ & \text { STYLUS SCAN } & 2 \mathrm{sec} \\ & \text { PAPER } & 200 \mathrm{ine} / \mathrm{inch} \\ & \text { MEMORY SWEEP } & 6 \mathrm{sec} \\ & \text { FILTER } & 1 \mathrm{in} \\ \text { POLARITY } & + \\ \text { GAIN } & 2 \text { to } 4 \\ \text { CONTRAST } & -25 \\ & \text { THRESHOLD } & 4 \text { (FWC as needed) }\end{array}$

Digital Memory LSR Yields 5 repeat sweeps per fire.

Amplifier Innerspace with integral bandpass filter $120 / 20 \mathrm{~Hz}$.

MASSCOMP

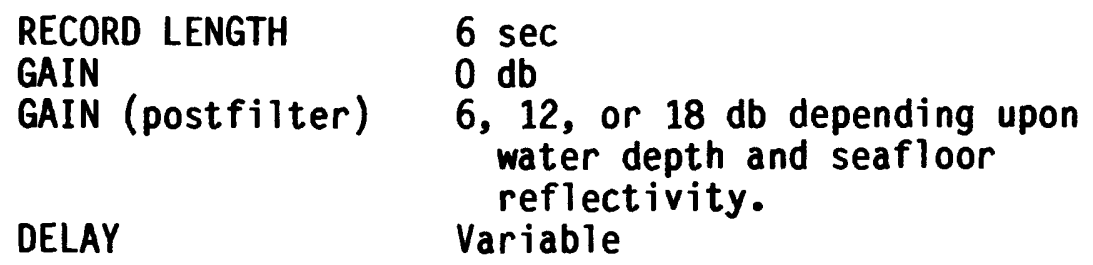

4. Gravimeter Standard operation; watchstander only checks gravity and spring tension values on the hour and marks the paper record with time, course, speed once an hour as part of the routine log entry. All adjustments or changes to operation are handles by the electronics tech or the designated navigator.

5. Magnetometer Standard operation; watchstander checks field value on the hour; logging procedures and equipment changes are the same as for other potential field data.

6. $\mathrm{XBT}$

One XBT probe every day at the change of watch at 1600 local. The NOAA recording unit has complete instructions for launching, plotting, and transmitting the data. Used T-4 probes provided by NOAA. 
APPENDIX 2 
START AND END COORDINATES FOR EACH OF THE TRACK LINES

\begin{tabular}{|c|c|c|c|c|}
\hline Line No. & & Latitude & Longitude & Hour $(Z) / J u l i a n d a y$ \\
\hline Line 1 & $\begin{array}{l}\text { Begin } \\
\text { End }\end{array}$ & $\begin{array}{l}19^{\circ} 25.6^{\prime} \mathrm{N} \\
21^{\circ} 29.0^{\prime}\end{array}$ & $\begin{array}{l}163^{\circ} 08.9^{\prime} \mathrm{W} \\
167^{\circ} 00.0^{\prime}\end{array}$ & $\begin{array}{l}0122 / 274 \\
0835 / 275\end{array}$ \\
\hline Line 2 & $\begin{array}{l}\text { Begin } \\
\text { End }\end{array}$ & $\begin{array}{l}21^{\circ} 29.0^{\prime} \\
21^{\circ} 10.5^{\prime}\end{array}$ & $\begin{array}{l}167^{\circ} 00.0^{\prime} \\
167^{\circ} 00.0^{\prime}\end{array}$ & $\begin{array}{l}0846 / 275 \\
1043 / 275\end{array}$ \\
\hline Line 3 & $\begin{array}{l}\text { Begin } \\
\text { End }\end{array}$ & $\begin{array}{l}21^{\circ} 10.5^{\prime} \\
20^{\circ} 18.0^{\prime}\end{array}$ & $\begin{array}{l}167^{\circ} 00.0^{\prime} \\
165^{\circ} 22.0^{\prime}\end{array}$ & $\begin{array}{l}1058 / 275 \\
0000 / 276\end{array}$ \\
\hline Line 4 & $\begin{array}{l}\text { Begin } \\
\text { End }\end{array}$ & $\begin{array}{l}20^{\circ} 18.0^{\prime} \\
20^{\circ} 05.0^{\prime}\end{array}$ & $\begin{array}{l}165^{\circ} 22.0^{\prime} \\
165^{\circ} 30.0^{\prime}\end{array}$ & $\begin{array}{l}0011 / 276 \\
0148 / 276\end{array}$ \\
\hline Line 5 & $\begin{array}{l}\text { Begin } \\
\text { End }\end{array}$ & $\begin{array}{l}20^{\circ} 05.0^{\prime} \\
20^{\circ} 51.0^{\prime}\end{array}$ & $\begin{array}{l}165^{\circ} 30.0^{\prime} \\
167^{\circ} 00.0^{\prime}\end{array}$ & $\begin{array}{l}1158 / 276 \\
1358 / 276\end{array}$ \\
\hline Line 6 & $\begin{array}{l}\text { Begin } \\
\text { End }\end{array}$ & $\begin{array}{l}20^{\circ} 51.0^{\prime} \\
21^{\circ} 44.1^{\prime}\end{array}$ & $\begin{array}{l}167^{\circ} 00.0^{\prime} \\
166^{\circ} 51.0^{\prime}\end{array}$ & $\begin{array}{l}1406 / 276 \\
2059 / 276\end{array}$ \\
\hline Line 7 & $\begin{array}{l}\text { Begin } \\
\text { End }\end{array}$ & $\begin{array}{l}21^{\circ} 44.1^{\prime} \\
19^{\circ} 19.9^{\prime}\end{array}$ & $\begin{array}{l}166^{\circ} 51.0^{\prime} \\
162^{\circ} 23.7^{\prime}\end{array}$ & $\begin{array}{l}2111 / 276 \\
0837 / 278\end{array}$ \\
\hline Line 8 & $\begin{array}{l}\text { Begin } \\
\text { End }\end{array}$ & $\begin{array}{l}19^{\circ} 19.9^{\prime} \\
19^{\circ} 26.5^{\prime}\end{array}$ & $\begin{array}{l}162^{\circ} 23.7^{\prime} \\
162^{\circ} 01.0^{\prime}\end{array}$ & $\begin{array}{l}0848 / 278 \\
1117 / 278\end{array}$ \\
\hline Line 9 & $\begin{array}{l}\text { Begin } \\
\text { End }\end{array}$ & $\begin{array}{l}19^{\circ} 26.5^{\prime} \\
21^{\circ} 56.0^{\prime}\end{array}$ & $\begin{array}{l}162^{\circ} 01.0^{\prime} \\
166^{\circ} 39.0^{\prime}\end{array}$ & $\begin{array}{l}1130 / 278 \\
0017 / 280\end{array}$ \\
\hline Line 10 & $\begin{array}{l}\text { Begin } \\
\text { End }\end{array}$ & $\begin{array}{l}21^{\circ} 56.0^{\prime} \\
22^{\circ} 09.0^{\prime}\end{array}$ & $\begin{array}{l}166^{\circ} 39.0^{\prime} \\
166^{\circ} 28.5^{\prime}\end{array}$ & $\begin{array}{l}0026 / 280 \\
0220 / 280\end{array}$ \\
\hline Line 11 & $\begin{array}{l}\text { Begin } \\
\text { End }\end{array}$ & $\begin{array}{l}22^{\circ} 09.0^{\prime} \\
19^{\circ} 39.0^{\prime}\end{array}$ & $\begin{array}{l}166^{\circ} 28.5^{\prime} \\
161^{\circ} 51.0^{\prime}\end{array}$ & $\begin{array}{l}0232 / 280 \\
1608 / 281\end{array}$ \\
\hline Line 12 & $\begin{array}{l}\text { Begin } \\
\text { End }\end{array}$ & $\begin{array}{l}19^{\circ} 39.0^{\prime} \\
19^{\circ} 53.0^{\prime}\end{array}$ & $\begin{array}{l}161^{\circ} 51.0^{\prime} \\
161^{\circ} 42.0^{\prime}\end{array}$ & $\begin{array}{l}1618 / 281 \\
1800 / 281\end{array}$ \\
\hline Line 13 & $\begin{array}{l}\text { Begin } \\
\text { End }\end{array}$ & $\begin{array}{l}19^{\circ} 53.0^{\prime} \\
22^{\circ} 23.0^{\prime}\end{array}$ & $\begin{array}{l}161^{\circ} 42.0^{\prime} \\
166^{\circ} 20.5^{\prime}\end{array}$ & $\begin{array}{l}1824 / 281 \\
0711 / 283\end{array}$ \\
\hline Line 14 & $\begin{array}{l}\text { Begin } \\
\text { End }\end{array}$ & $\begin{array}{l}22^{\circ} 23.0^{\prime} \\
22^{\circ} 32.5^{\prime}\end{array}$ & $\begin{array}{l}166^{\circ} 20.5^{\prime} \\
166^{\circ} 06.0^{\prime}\end{array}$ & $\begin{array}{l}0723 / 283 \\
0909 / 283\end{array}$ \\
\hline Line 15 & $\begin{array}{l}\text { Begin } \\
\text { End }\end{array}$ & $\begin{array}{l}22^{\circ} 32.5^{\prime} \\
19^{\circ} 48.0^{\prime}\end{array}$ & $\begin{array}{l}166^{\circ} 06.0^{\prime} \\
161^{\circ} 00.0^{\prime}\end{array}$ & $\begin{array}{l}0919 / 283 \\
0044 / 285\end{array}$ \\
\hline Line 16 & $\begin{array}{l}\text { Begin } \\
\text { End }\end{array}$ & $\begin{array}{l}19^{\circ} 48.0^{\prime} \\
20^{\circ} 02.5^{\prime}\end{array}$ & $\begin{array}{l}161^{\circ} 00.0^{\prime} \\
160^{\circ} 50.5^{\prime}\end{array}$ & $\begin{array}{l}0100 / 285 \\
0242 / 285\end{array}$ \\
\hline
\end{tabular}




\begin{tabular}{|c|c|c|c|c|}
\hline Line 17 & $\begin{array}{l}\text { Begin } \\
\text { End }\end{array}$ & $\begin{array}{l}20^{\circ} 02.5^{\prime} \\
22^{\circ} 42.0^{\prime}\end{array}$ & $\begin{array}{l}160^{\circ} 50.5^{\prime} \\
165^{\circ} 51.0^{\prime}\end{array}$ & $\begin{array}{l}0252 / 285 \\
1429 / 286\end{array}$ \\
\hline Line 18 & $\begin{array}{l}\text { Begin } \\
\text { End }\end{array}$ & $\begin{array}{l}22^{\circ} 42.0^{\prime} \\
22^{\circ} 52.0^{\prime}\end{array}$ & $\begin{array}{l}165^{\circ} 51.0^{\prime} \\
165^{\circ} 35.5^{\prime}\end{array}$ & $\begin{array}{l}1442 / 286 \\
1630 / 286\end{array}$ \\
\hline Line 19 & $\begin{array}{l}\text { Begin } \\
\text { End }\end{array}$ & $\begin{array}{l}22^{\circ} 52.0^{\prime} \\
20^{\circ} 16.0^{\prime}\end{array}$ & $\begin{array}{l}165^{\circ} 35.5^{\prime} \\
160^{\circ} 42.4^{\prime}\end{array}$ & $\begin{array}{l}1635 / 286 \\
0712 / 288\end{array}$ \\
\hline Line 20 & $\begin{array}{l}\text { Begin } \\
\text { End }\end{array}$ & $\begin{array}{l}20^{\circ} 16.0^{\prime} \\
20^{\circ} 30.0^{\prime}\end{array}$ & $\begin{array}{l}160^{\circ} 42.4^{\prime} \\
160^{\circ} 34.0^{\prime}\end{array}$ & $\begin{array}{l}0722 / 288 \\
0900 / 288\end{array}$ \\
\hline Line 21 & $\begin{array}{l}\text { Begin } \\
\text { End }\end{array}$ & $\begin{array}{l}20^{\circ} 30.0^{\prime} \\
23^{\circ} 03.0^{\prime}\end{array}$ & $\begin{array}{l}160^{\circ} 34.0^{\prime} \\
165^{\circ} 21.0^{\prime}\end{array}$ & $\begin{array}{l}0910 / 288 \\
2106 / 289\end{array}$ \\
\hline Line 22 & $\begin{array}{l}\text { Begin } \\
\text { End }\end{array}$ & $\begin{array}{l}23^{\circ} 03.0^{\prime} \\
22^{\circ} 14.5^{\prime}\end{array}$ & $\begin{array}{l}165^{\circ} 21.0^{\prime} \\
166^{\circ} 39.2^{\prime}\end{array}$ & $\begin{array}{l}2115 / 289 \\
0631 / 290\end{array}$ \\
\hline Line 23 & $\begin{array}{l}\text { Begin } \\
\text { End }\end{array}$ & $\begin{array}{l}22^{\circ} 14.5^{\prime} \\
22^{\circ} 28.0^{\prime}\end{array}$ & $\begin{array}{l}166^{\circ} 39.2^{\prime} \\
166^{\circ} 49.0^{\prime}\end{array}$ & $\begin{array}{l}0639 / 290 \\
0832 / 290\end{array}$ \\
\hline Line 24 & $\begin{array}{l}\text { Begin } \\
\text { End }\end{array}$ & $\begin{array}{l}22^{\circ} 28.0^{\prime} \\
23^{\circ} 21.5^{\prime}\end{array}$ & $\begin{array}{l}166^{\circ} 49.0^{\prime} \\
165^{\circ} 21.0^{\prime}\end{array}$ & $\begin{array}{l}0842 / 290 \\
2021 / 290\end{array}$ \\
\hline Line 25 & $\begin{array}{l}\text { Begin } \\
\text { End }\end{array}$ & $\begin{array}{l}23^{\circ} 21.5^{\prime} \\
20^{\circ} 44.0^{\prime}\end{array}$ & $\begin{array}{l}165^{\circ} 21.0^{\prime} \\
160^{\circ} 25.0^{\prime}\end{array}$ & $\begin{array}{l}2030 / 290 \\
0933 / 292\end{array}$ \\
\hline Line 26 & $\begin{array}{l}\text { Begin } \\
\text { End }\end{array}$ & $\begin{array}{l}20^{\circ} 44.0^{\prime} \\
20^{\circ} 58.0^{\prime}\end{array}$ & $\begin{array}{l}160^{\circ} 25.0^{\prime} \\
160^{\circ} 17.0^{\prime}\end{array}$ & $\begin{array}{l}0942 / 292 \\
1123 / 292\end{array}$ \\
\hline Line 27 & $\begin{array}{l}\text { Begin } \\
\text { End }\end{array}$ & $\begin{array}{l}20^{\circ} 58.0^{\prime} \\
23^{\circ} 00.0^{\prime}\end{array}$ & $\begin{array}{l}160^{\circ} 17.0^{\prime} \\
164^{\circ} 08.5^{\prime}\end{array}$ & $\begin{array}{l}1133 / 292 \\
1626 / 293\end{array}$ \\
\hline Line 28 & $\begin{array}{l}\text { Begin } \\
\text { End }\end{array}$ & $\begin{array}{l}23^{\circ} 00.0^{\prime} \\
23^{\circ} 13.5^{\prime}\end{array}$ & $\begin{array}{l}164^{\circ} 08.5^{\prime} \\
163^{\circ} 56.0^{\prime}\end{array}$ & $\begin{array}{l}1636 / 293 \\
1835 / 293\end{array}$ \\
\hline Line 29 & $\begin{array}{l}\text { Begin } \\
\text { End }\end{array}$ & $\begin{array}{l}23^{\circ} 13.5^{\prime} \\
21^{\circ} 20.5^{\prime}\end{array}$ & $\begin{array}{l}163^{\circ} 56.0^{\prime} \\
160^{\circ} 25.0^{\prime}\end{array}$ & $\begin{array}{l}1841 / 293 \\
1933 / 294\end{array}$ \\
\hline Line $30 \mathrm{~A}$ & $\begin{array}{l}\text { Begin } \\
\text { End }\end{array}$ & $\begin{array}{l}21^{\circ} 20.5^{\prime} \\
21^{\circ} 33.5^{\prime}\end{array}$ & $\begin{array}{l}160^{\circ} 25.0^{\prime} \\
160^{\circ} 28.0^{\prime}\end{array}$ & $\begin{array}{l}1942 / 294 \\
2058 / 294\end{array}$ \\
\hline Line $30 \mathrm{~B}$ & $\begin{array}{l}\text { Begin } \\
\text { End }\end{array}$ & $\begin{array}{l}21^{\circ} 33.5^{\prime} \\
21^{\circ} 36.5^{\prime}\end{array}$ & $\begin{array}{l}160^{\circ} 28.0^{\prime} \\
160^{\circ} 41.0^{\prime}\end{array}$ & $\begin{array}{l}2108 / 294 \\
2222 / 294\end{array}$ \\
\hline Line $30 \mathrm{C}$ & $\begin{array}{l}\text { Begin } \\
\text { End }\end{array}$ & $\begin{array}{l}21^{\circ} 36.5^{\prime} \\
21^{\circ} 46.5^{\prime}\end{array}$ & $\begin{array}{l}160^{\circ} 41.0^{\prime} \\
160^{\circ} 37.5^{\prime}\end{array}$ & $\begin{array}{l}2230 / 294 \\
2330 / 294\end{array}$ \\
\hline Line 30D & $\begin{array}{l}\text { Begin } \\
\text { End }\end{array}$ & $\begin{array}{l}21^{\circ} 46.5^{\prime} \\
21^{\circ} 42.0^{\prime}\end{array}$ & $\begin{array}{l}160^{\circ} 37.5^{\prime} \\
160^{\circ} 30.0^{\prime}\end{array}$ & $\begin{array}{l}2338 / 294 \\
0025 / 295\end{array}$ \\
\hline Line $31 \mathrm{~A}$ & $\begin{array}{l}\text { Begin } \\
\text { End }\end{array}$ & $\begin{array}{l}21^{\circ} 42.0^{\prime} \\
21^{\circ} 46.5^{\prime}\end{array}$ & $\begin{array}{l}160^{\circ} 30.0^{\prime} \\
160^{\circ} 22.0^{\prime}\end{array}$ & $\begin{array}{l}0032 / 295 \\
0132 / 295\end{array}$ \\
\hline
\end{tabular}




$\begin{array}{lllll}\text { Line 31B } & \begin{array}{l}\text { Begin } \\ \text { End }\end{array} & 21^{\circ} 46.5^{\prime} & 160^{\circ} 22.0^{\prime} & 0129 / 295 \\ & 21^{\circ} 56.5^{\prime} & 160^{\circ} 22.0^{\prime} & 0228 / 295 \\ \text { Line 31C } & \begin{array}{l}\text { Begin } \\ \text { End }\end{array} & 21^{\circ} 56.5^{\prime} & 160^{\circ} 22.0^{\prime} & 0236 / 295 \\ & 21^{\circ} 59.5^{\prime} & 160^{\circ} 32.0^{\prime} & 0332 / 295 \\ \text { Line 31D } & \begin{array}{l}\text { Begin } \\ \text { End }\end{array} & 21^{\circ} 59.5^{\prime} & 160^{\circ} 32.0^{\prime} & 0342 / 295 \\ & 21^{\circ} 51.0^{\prime} & 160^{\circ} 32.0^{\prime} & 0428 / 295 \\ \text { Line 32A } & \begin{array}{l}\text { Begin } \\ \text { End }\end{array} & 21^{\circ} 51.0^{\prime} & 160^{\circ} 32.0^{\prime} & 0436 / 295 \\ & 21^{\circ} 50.0^{\prime} & 160^{\circ} 53.5^{\prime} & 0647 / 295 \\ \text { Line 32B } & \begin{array}{l}\text { Begin } \\ \text { End }\end{array} & 21^{\circ} 50.0^{\prime} & 160^{\circ} 53.5^{\prime} & 0650 / 295 \\ & 21^{\circ} 58.0^{\prime} & 161^{\circ} 04.5^{\prime} & 0813 / 295 \\ \text { Line 32C } & \begin{array}{l}\text { Begin } \\ \text { End }\end{array} & 21^{\circ} 58.0^{\prime} & 161^{\circ} 04.5^{\prime} & 0815 / 295 \\ & 22^{\circ} 27.5^{\prime} & 162^{\circ} 00.0^{\prime} & 1435 / 295 \\ \text { Line 33 } & \begin{array}{l}\text { Begin } \\ \text { End }\end{array} & 22^{\circ} 27.5^{\prime} & 162^{\circ} 00.0^{\prime} & 1448 / 295 \\ & 22^{\circ} 26.5^{\prime} & 161^{\circ} 35.5^{\prime} & 1716 / 295 \\ \text { Line 34 } & \begin{array}{l}\text { Begin } \\ \text { End }\end{array} & 22^{\circ} 26.5^{\prime} & 161^{\circ} 35.5^{\prime} & 1720 / 295 \\ & 22^{\circ} 00.0^{\prime} & 160^{\circ} 38.5^{\prime} & 0037 / 296\end{array}$




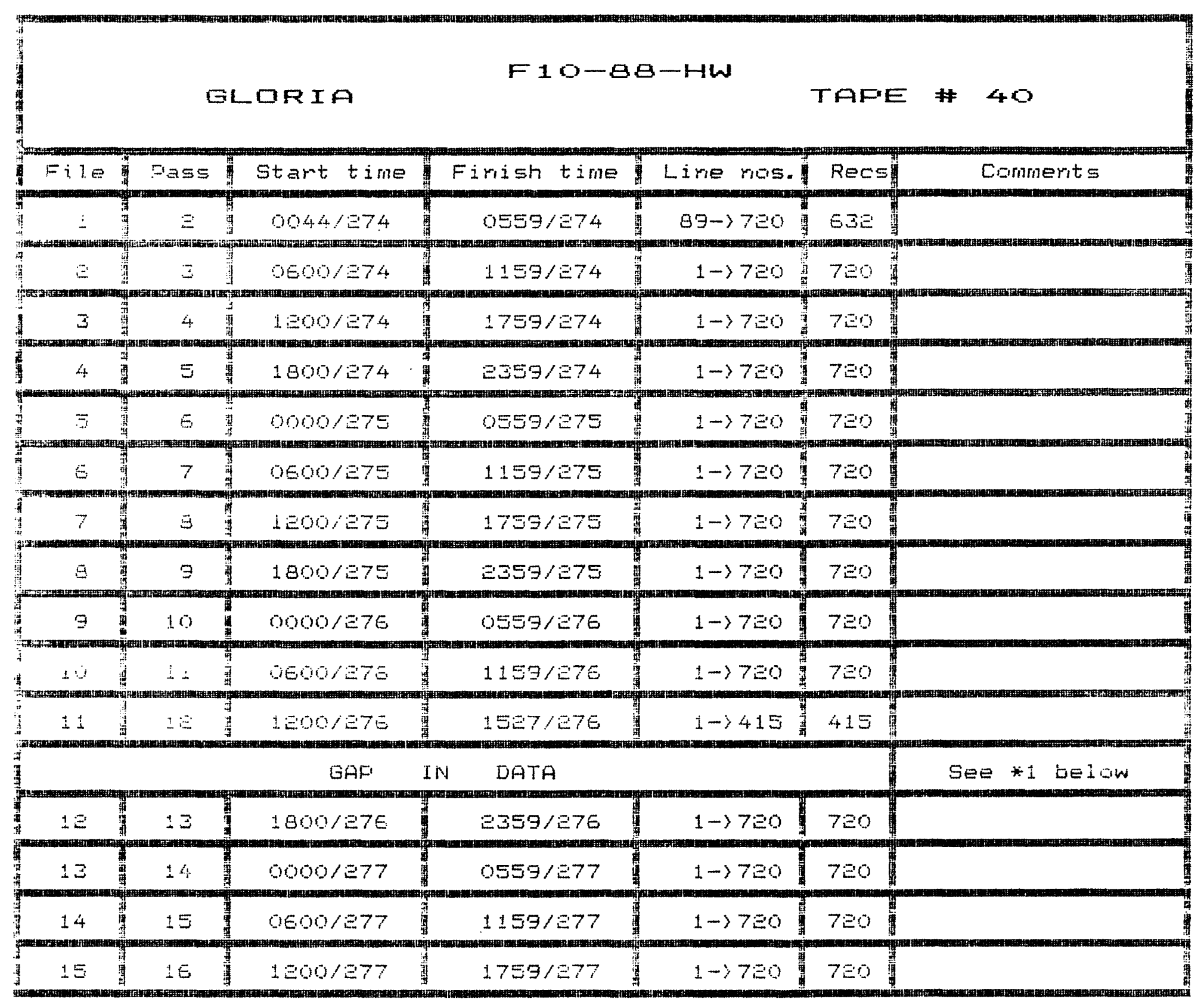

Tota i mumber of pecomds $=10407$

+ - Failuro in onip's mairs supplies. 


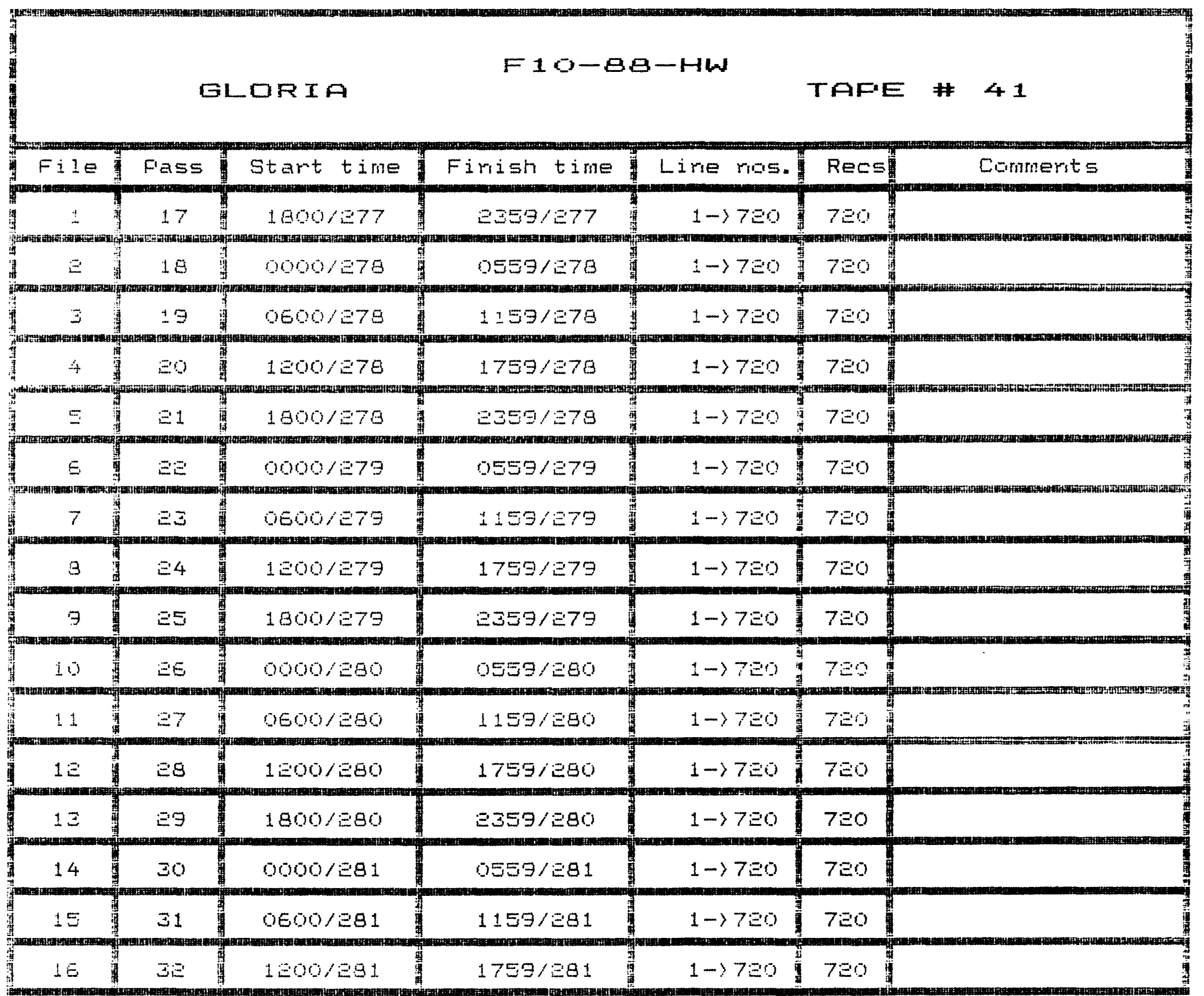

Total rumber of recards = 11500 


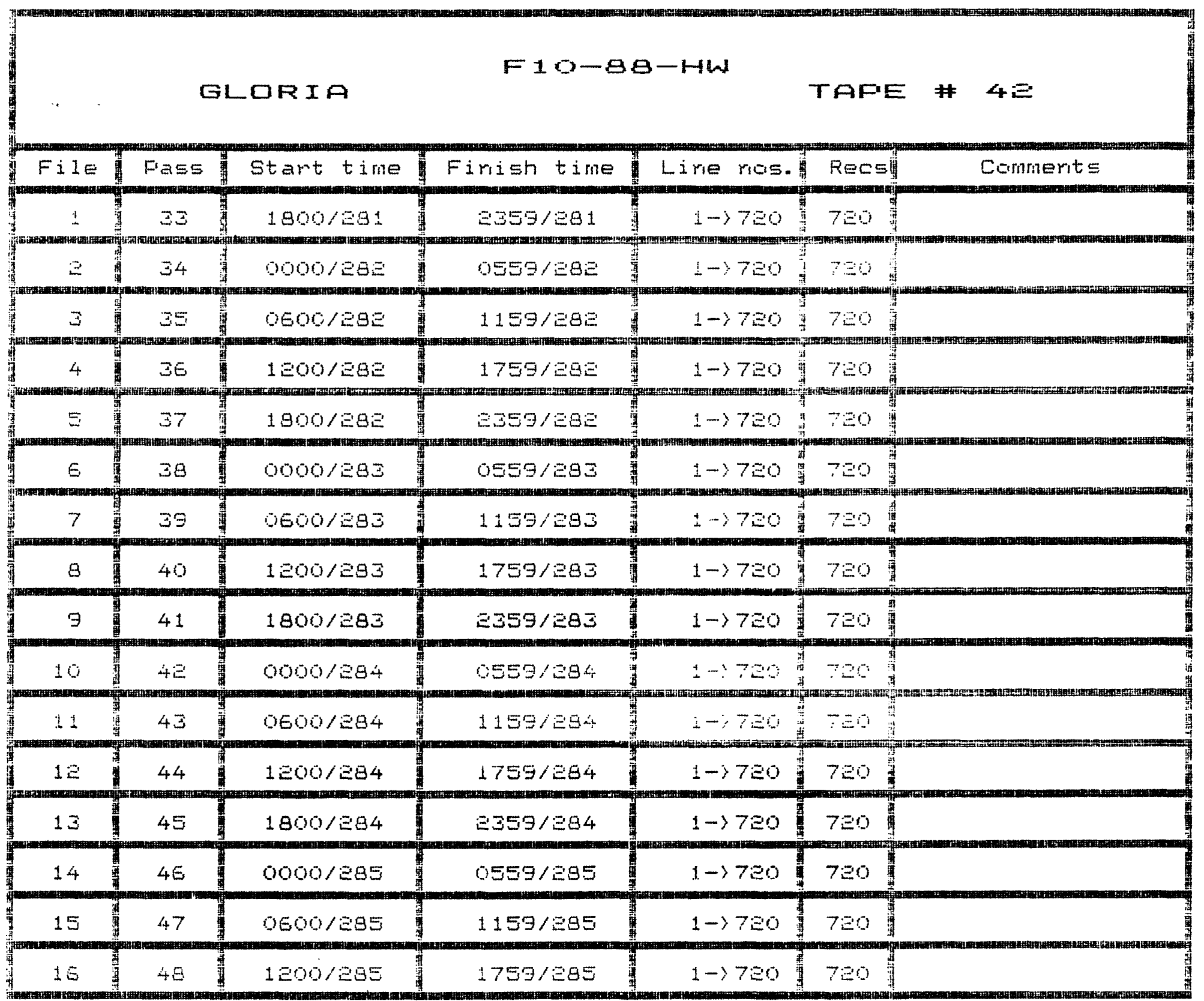

Total number af records = $115 \Xi 0$ 


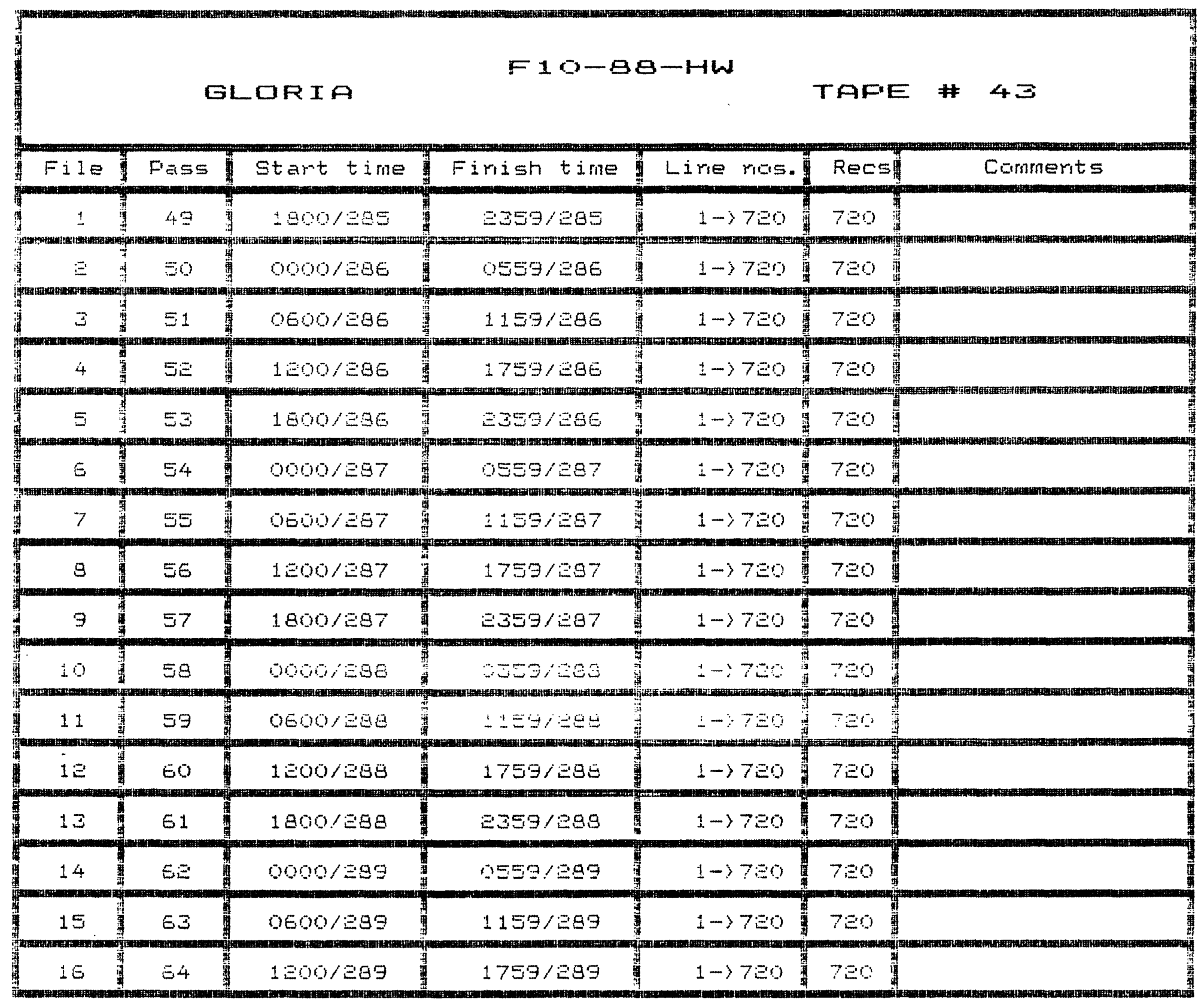

Tatal rumber of recards = 11 ESO 


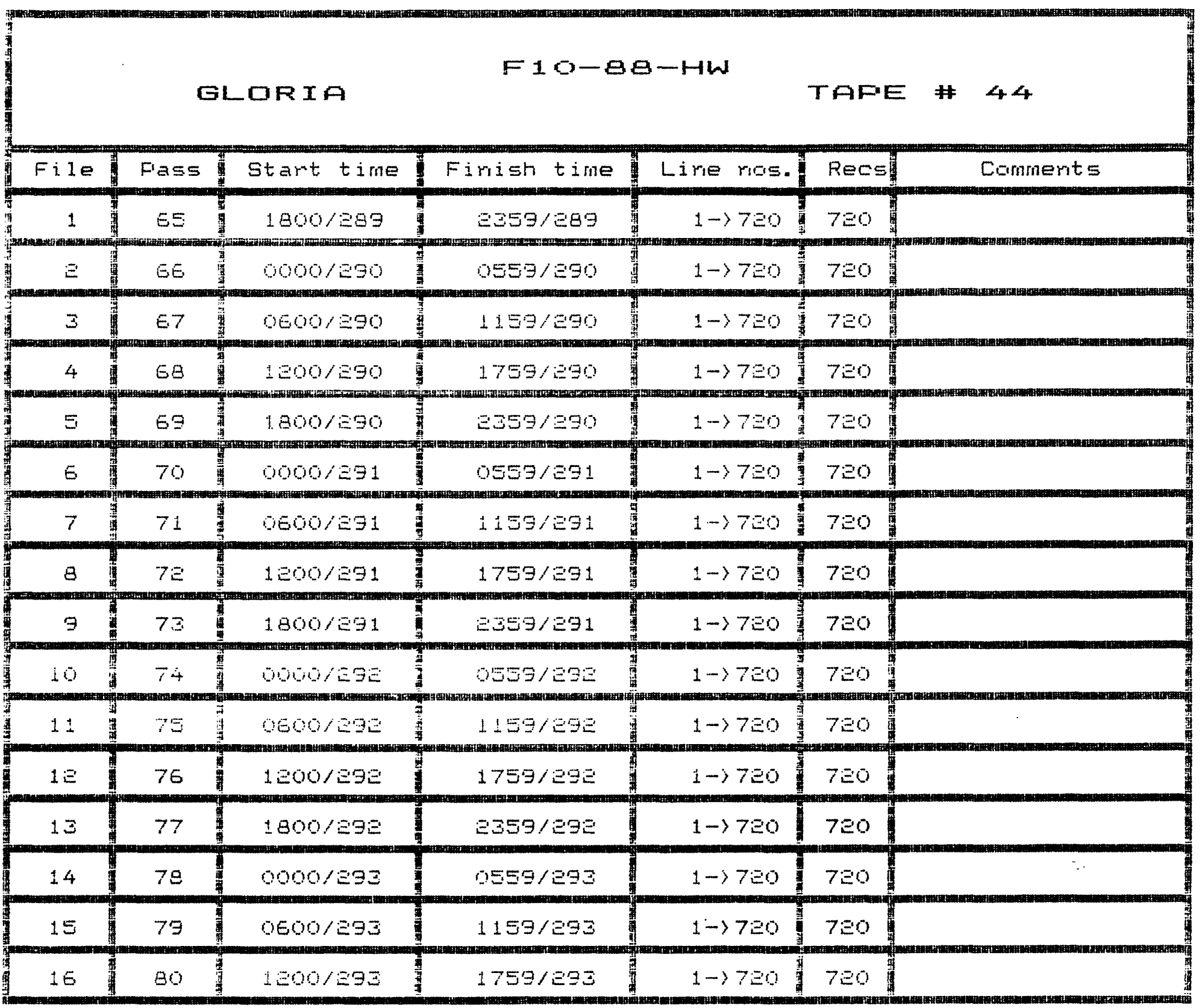

Total number af recomds=115E0 


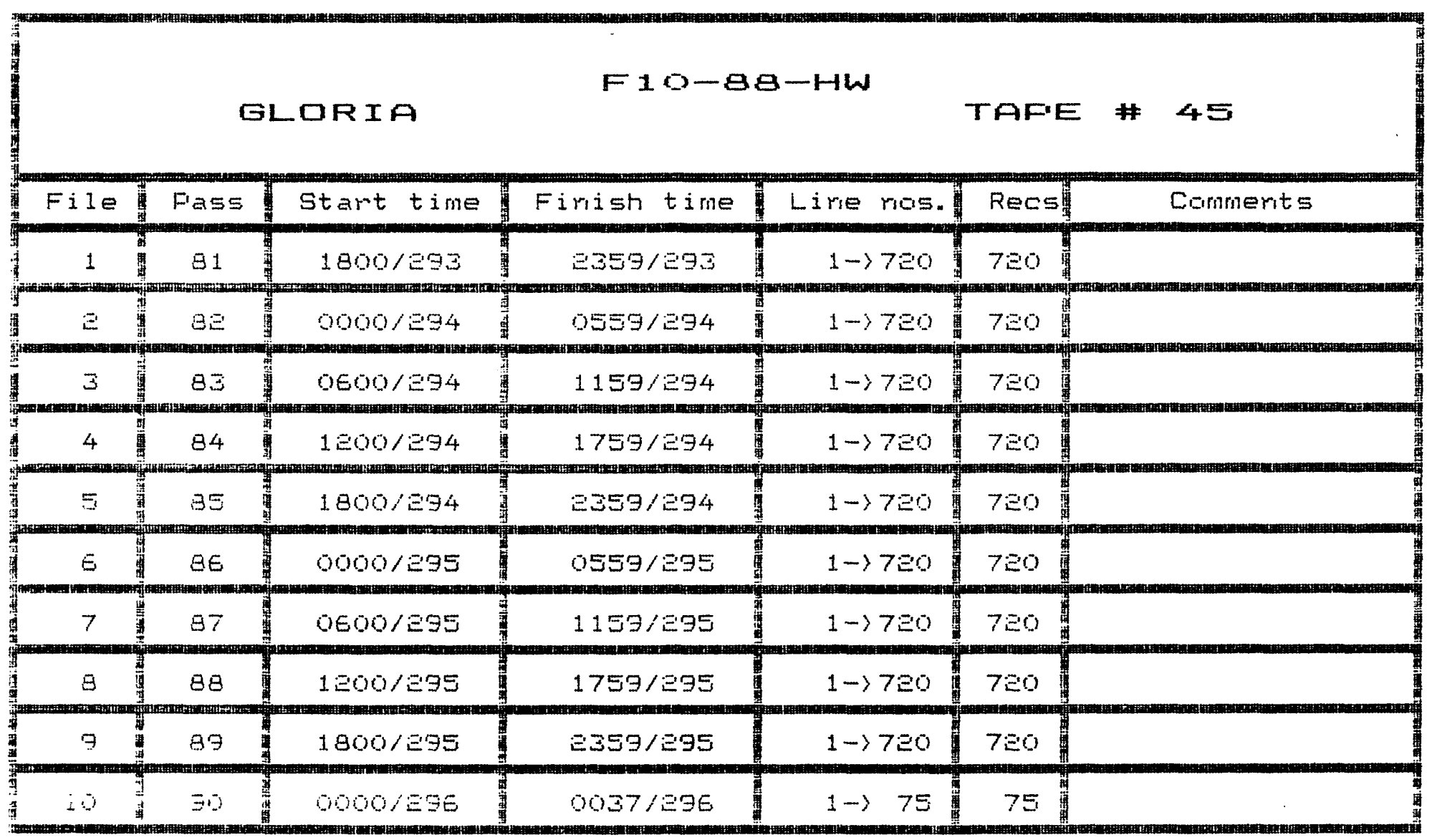

Tetal rumber of recards = ESSE 


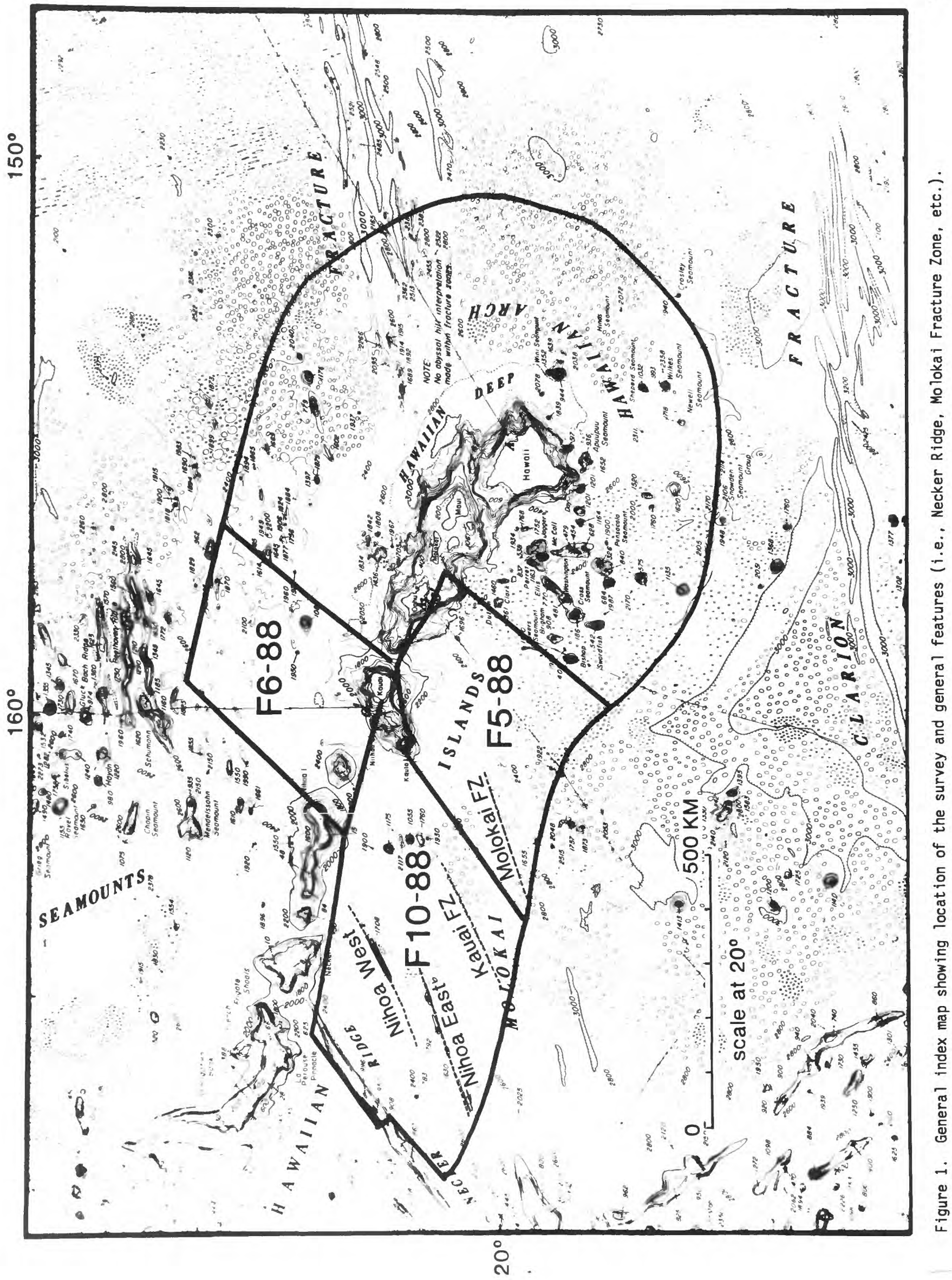




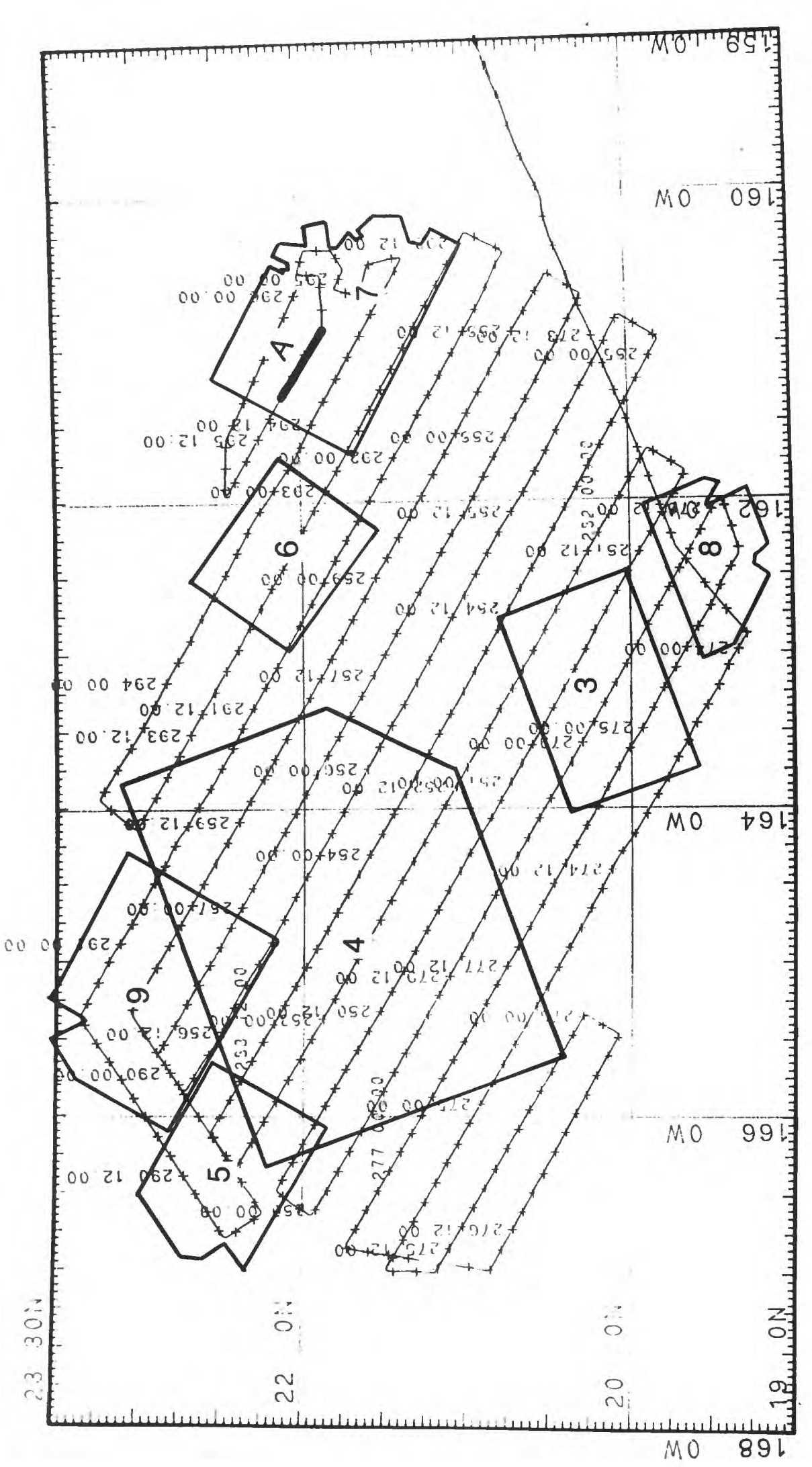

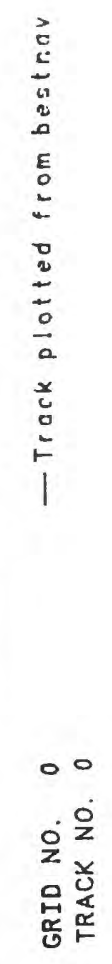

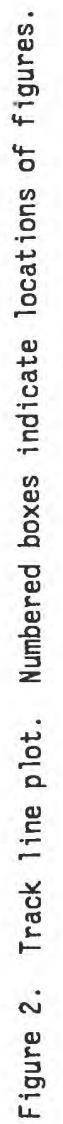




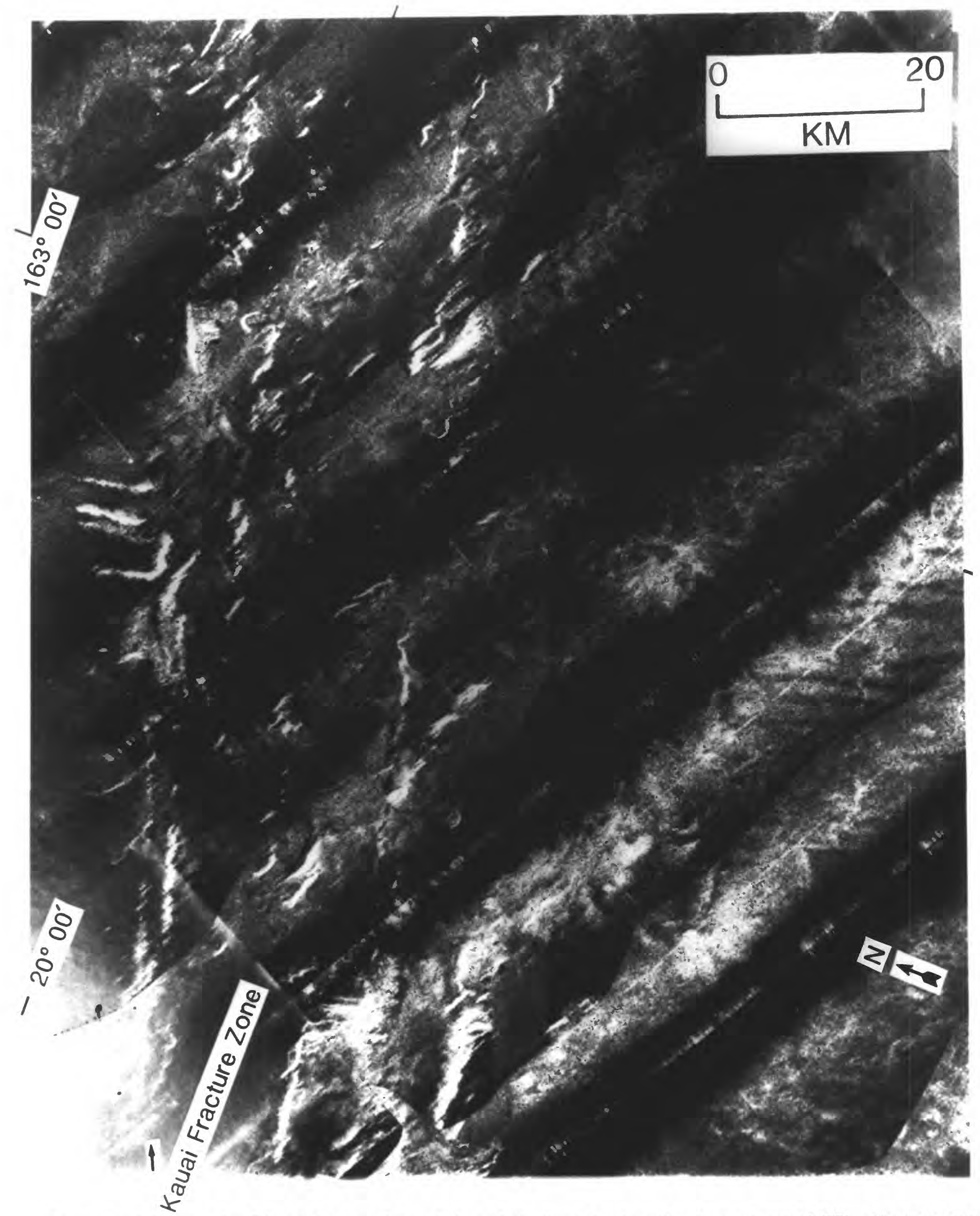

Figure 3. GLORIA mosaic of Kauai Fracture Zone. Ridges of the Kauai Fracture Zone have a trend of $075^{\circ}$. The Cretaceous seafloor grain is orthogonal to and bends in toward the fracture zone. 


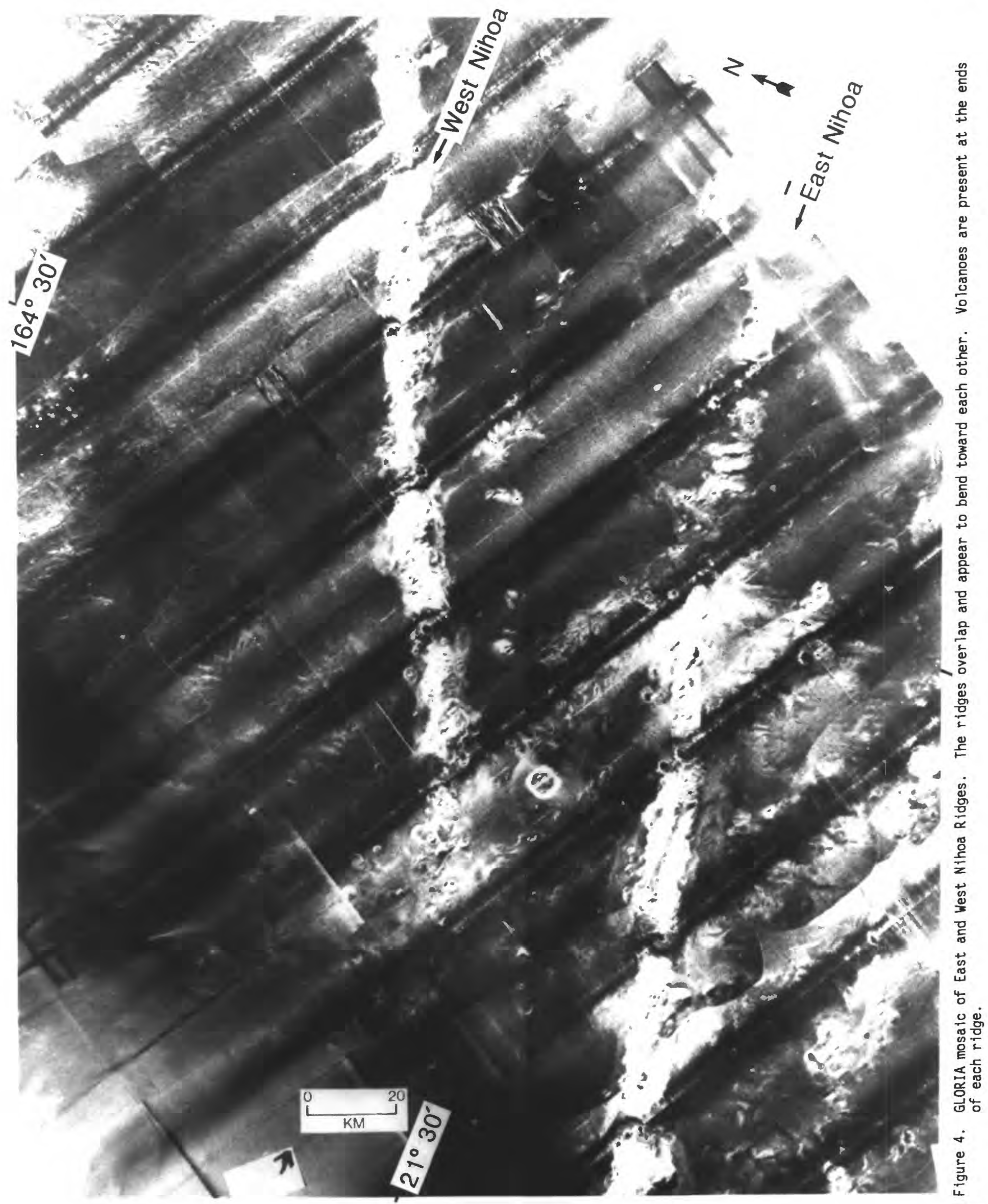




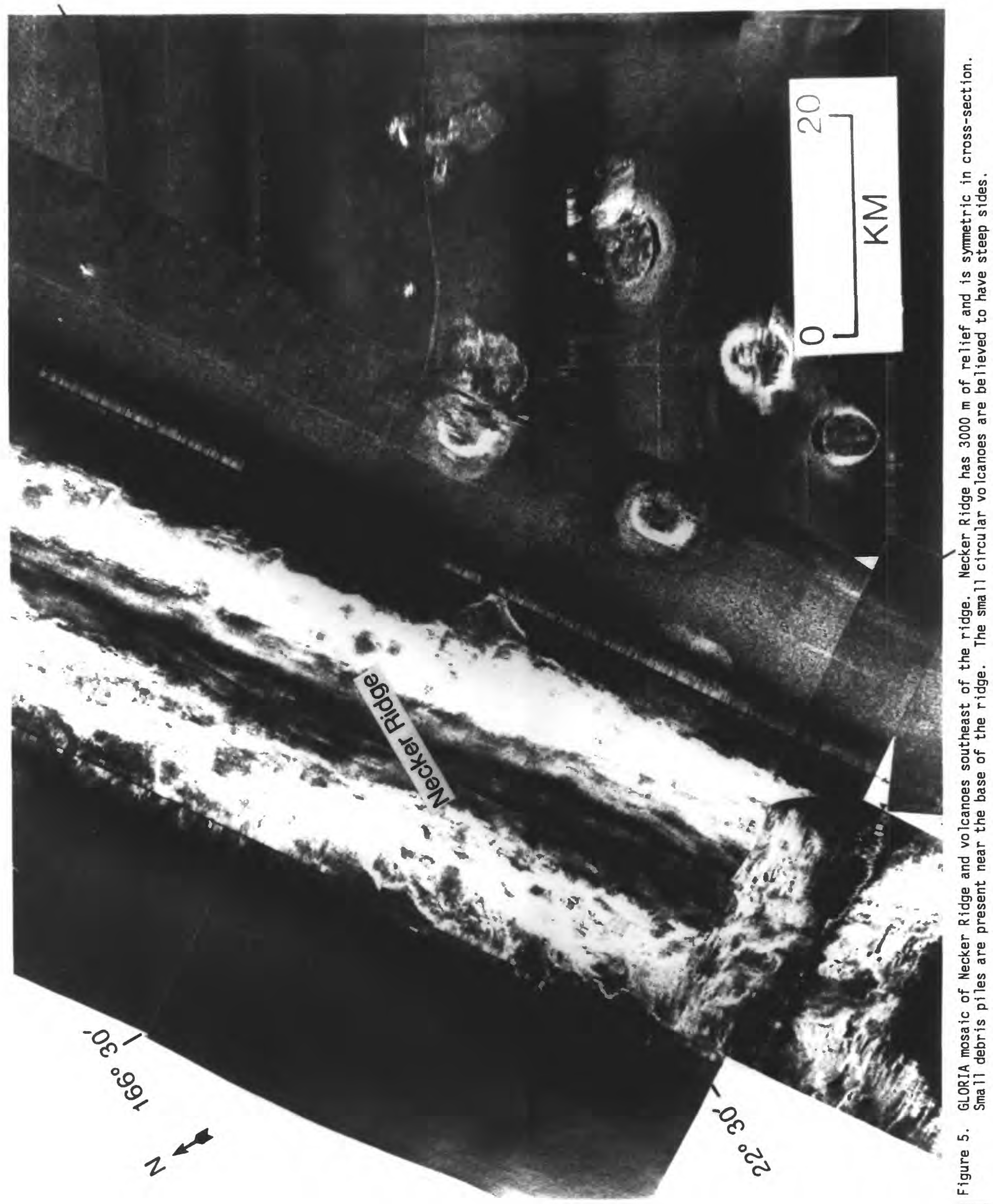




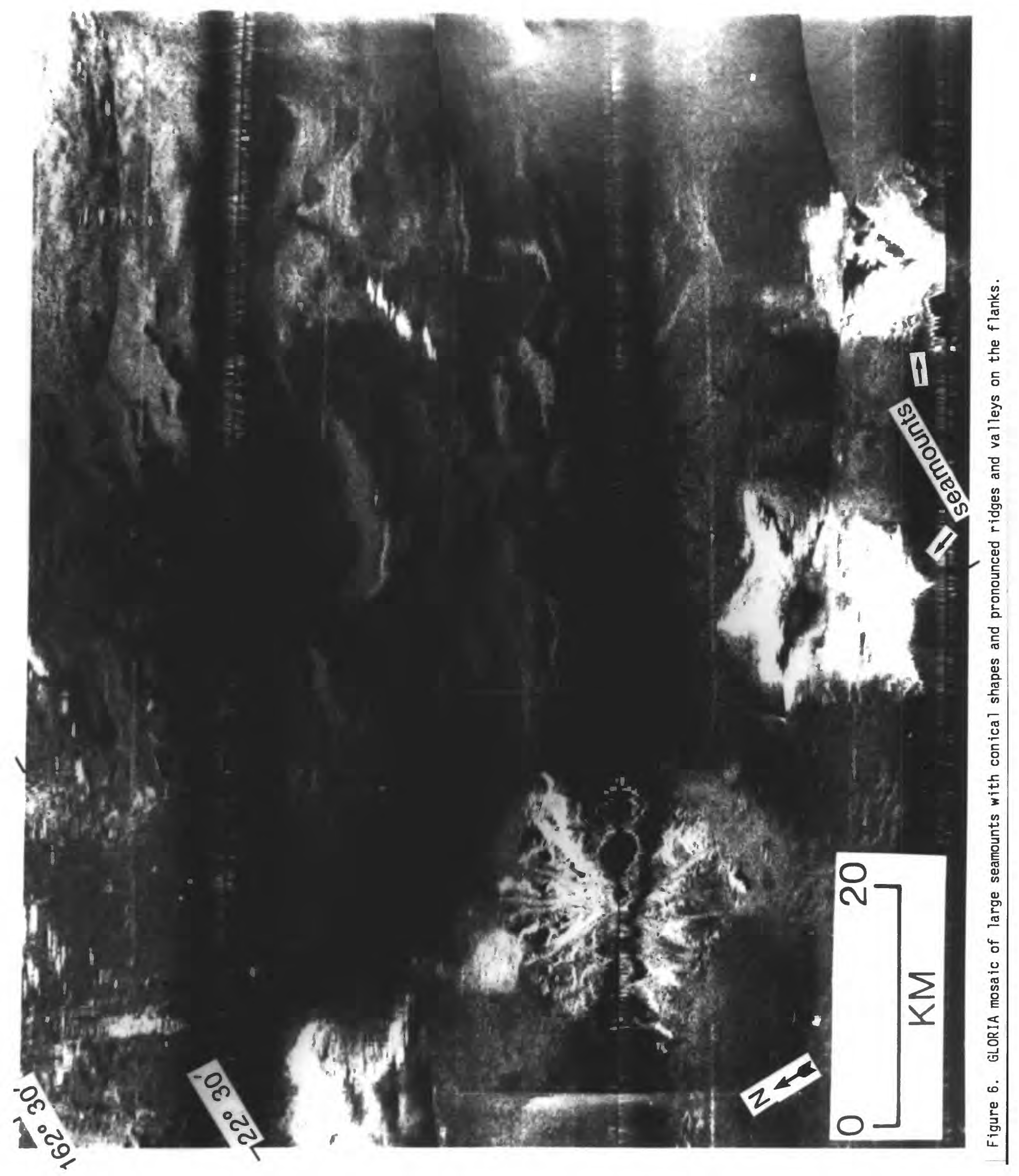




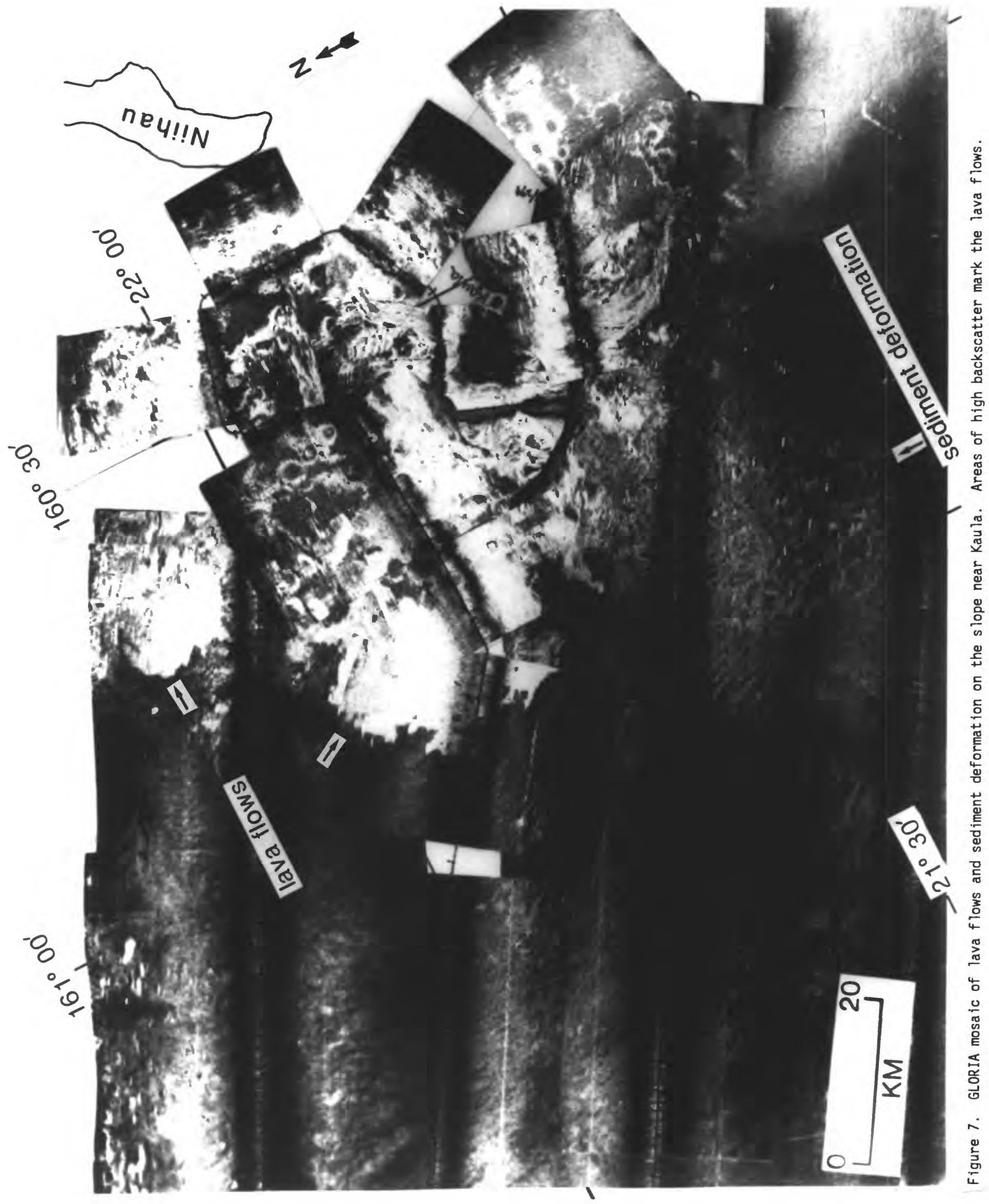




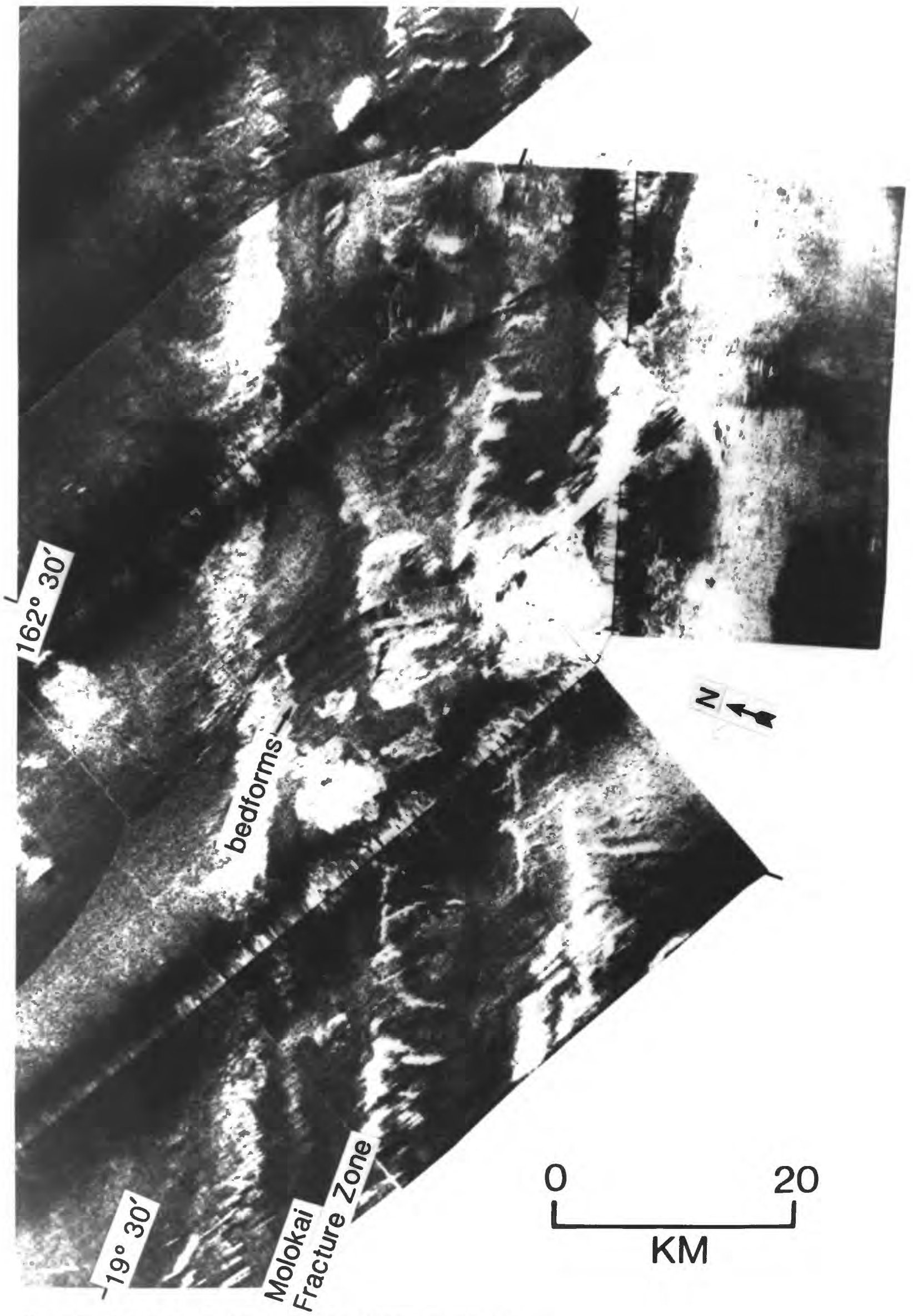

Figure 8. GLORIA image of bedforms in Moloka i Fracture Zone. 


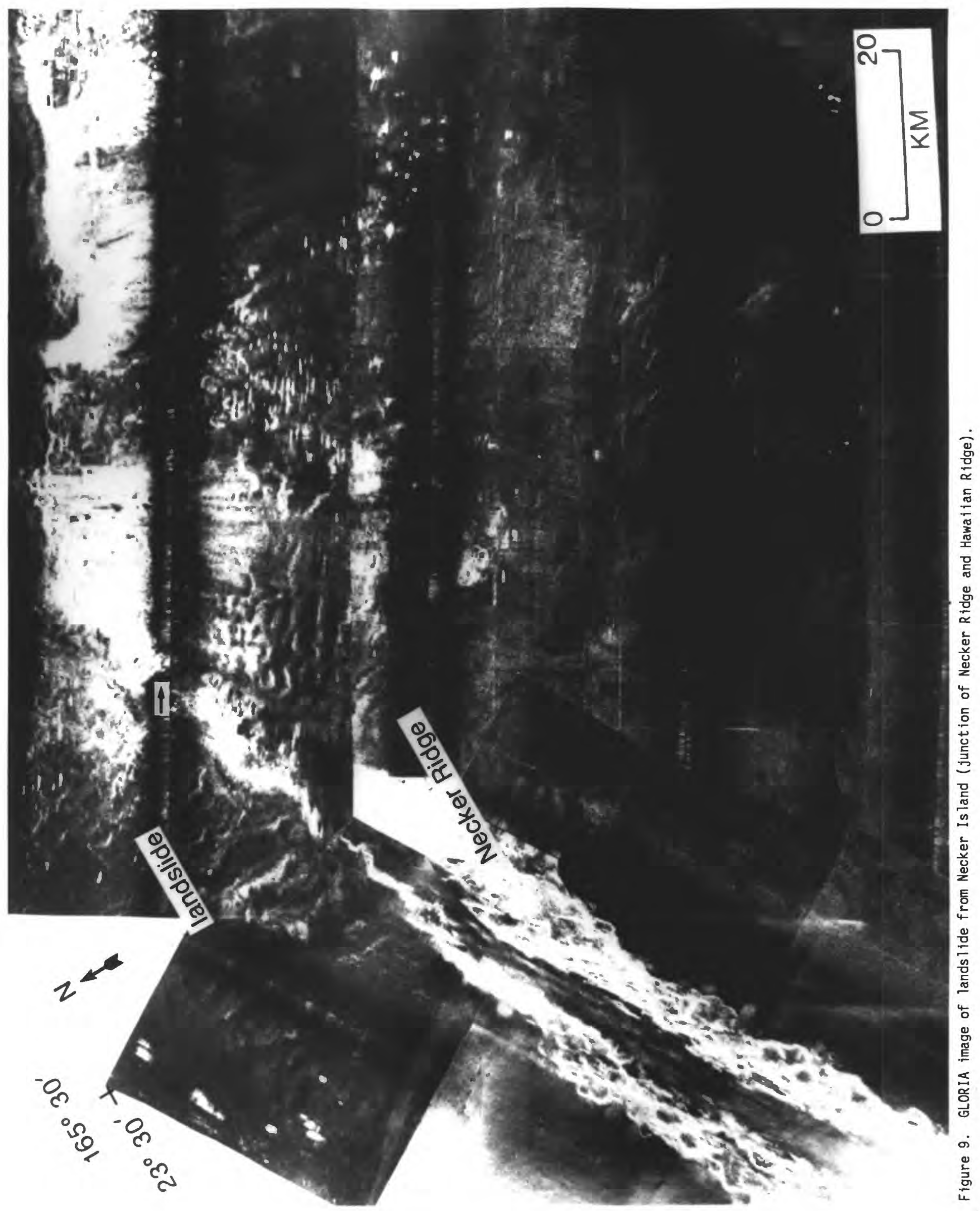




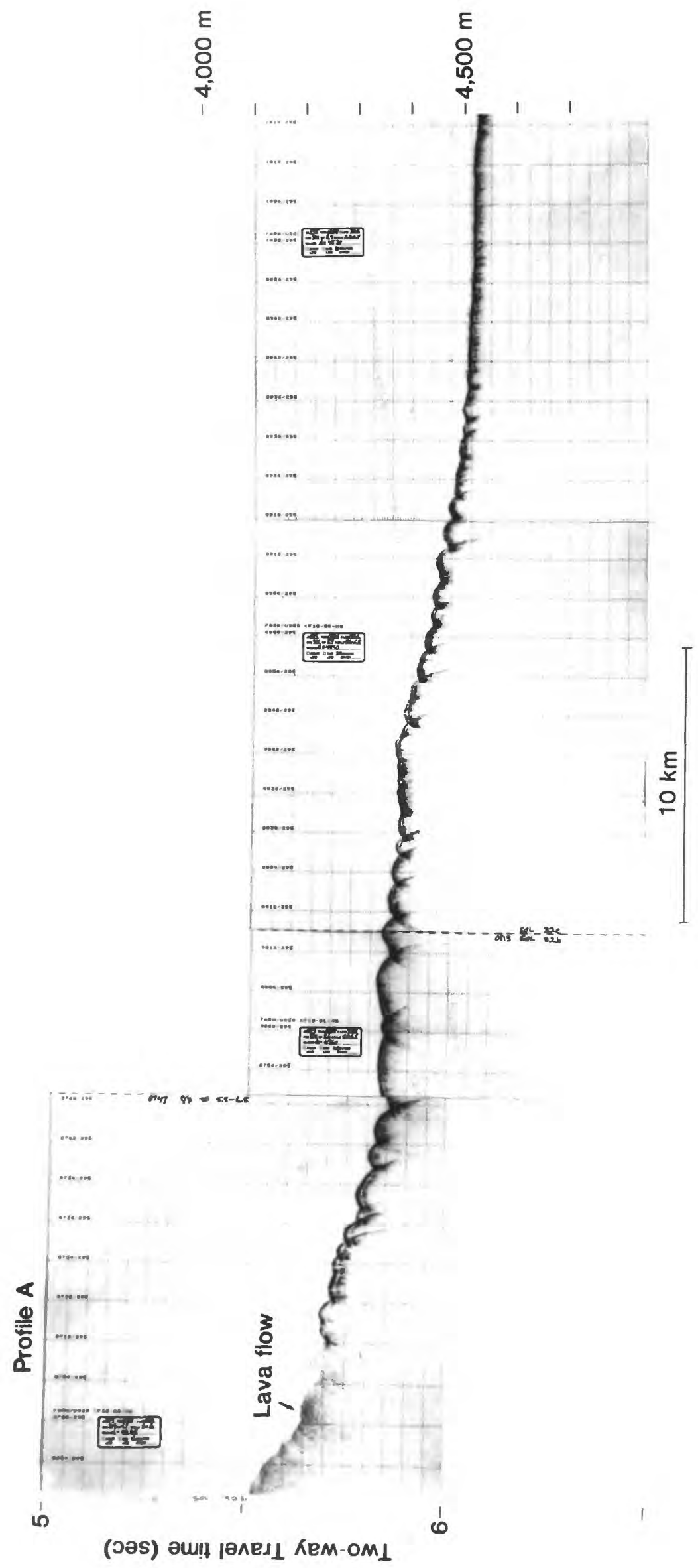

